\title{
PRIVATE CIVIL REMEDIES: A VIABLE TOOL FOR GUEST WORKER EMPOWERMENT
}

\begin{abstract}
Jennifer J. Lee*
Despite the well-known abuses of guest workers, the government has failed to curb them. Guest workers with $\mathrm{H}-2 \mathrm{~A}$ and $\mathrm{H}-2 \mathrm{~B}$ visas face appalling job conditions, including the confiscation of documents, wage and hour abuses, on-the-job injuries without treatment, unhealthy housing conditions, and verbal and physical abuse. Although multiple government agencies have failed to address the exploitation of guest workers, the government has authorized these workers to invoke private civil remedies. These remedies can become a means by which disadvantaged immigrant workers seek redress for their egregious exploitation, particularly given how severely disadvantaged such workers are in the political arena.

This Article examines to what end the devolution of rights via private civil remedies can be leveraged to benefit immigrant workers, giving them the opportunity to tell their own story while seeking justice for themselves and other workers. Ultimately, this Article argues that private civil remedies can play a modest role in vindicating the rights of guest workers while simultaneously producing counternarratives that combat cultural assumptions about guest workers, ultimately leading to guest worker empowerment.
\end{abstract}

* Managing Attorney, Migrant Farm Worker Division, Colorado Legal Services (CLS). I am grateful for the comments and suggestions of Deborah Weissman, Ragini Shah, and Linda Surbaugh. I would also like to thank the Loyola of Los Angeles Law Review for its excellent editorial assistance. The views expressed in this paper are those of the author and do not purport to represent the views of CLS. 
TABLE OF CONTENTS

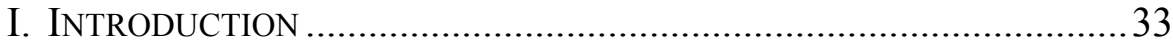

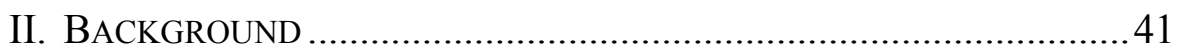

A. Guest Worker Programs Facilitate Labor Abuses ............. 41

B. Government Enforcement Is Inadequate ..........................44

III. PRIVATE CIVIL REMEDIES .........................................................50

A. Trafficking Victims Protection Act ................................50

B. Racketeer and Influenced Corrupt Organization Act.........56

C. Racial Harassment and Hostile Work Environment ..........62 62

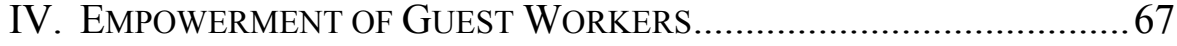

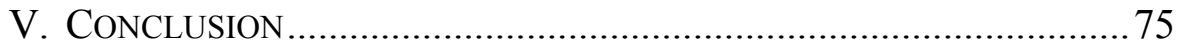




\section{INTRODUCTION}

On a sprawling ranch encompassing parts of Colorado, Wyoming, and Utah, a group of Chilean cattle herders worked for a prominent ranching family after being brought to the United States on $\mathrm{H}-2 \mathrm{~A}$ visas. ${ }^{1}$ While on the ranch, their employers held their documents and prevented them from personally accessing their earnings in the bank. ${ }^{2}$ They worked seven days per week, up to sixteen hours per day, and earned approximately two to three dollars per hour, often performing work in violation of their visas. ${ }^{3}$ One worker, who was thrown and kicked by a horse, not only had to wait seven days to be taken to a hospital, but was also forced to work through his head and chest injuries. ${ }^{4}$ After he filed a claim for worker's compensation, his boss subsequently interrogated him on videotape in order to get him to rescind his claim. ${ }^{5}$ When two other workers asked to leave, the boss denied them their money, passports, and documents and threatened them with deportation. ${ }^{6}$ Several of the workers ultimately escaped from the ranch, including two brothers who came across a hunter and used his cell phone to call for help.

After the workers' conditions came to light, federal law enforcement declined to prosecute the employer because the workers were not physically restrained, ${ }^{8}$ even though the recently enacted Victims of Trafficking and Violence Protection Act of 2000 (TVPA) provided grounds for prosecuting employers that obtain forced labor through nonphysical coercion. ${ }^{9}$ The U.S. Department of Labor

1. Brandon Johnson, Chilean Workers File Lawsuit, Say Dickinson Family Exploited Them, CRAIG DAILY PRESS (June 5, 2006), http://www.craigdailypress.com/news/2006/jun/05/chilean _workers_file.

2. Deborah Frazier, Attorney: Guest-Work System Can Be Abused, Rocky MounTAIN NEWS (June 3, 2006, 12:00 AM), http://m.rockymountainnews.com/news/2006/Jun/03/attorney -guest-work-system-can-be-abused/.

3. Id.

4. Id.

5. VERITÉ, IMMigrant WORKERS IN US AgRiculture: THE ROLE OF LABOR BROKERS IN VULNERABILITY TO FORCED LABOR 96-97 (2010).

6. Frazier, supra note 2.

7. Id.

8. Telephone Interview with Kimi Jackson, Attorney, ProBAR (Jan. 3, 2012).

9. Victims of Trafficking and Violence Protection Act of 2000, Pub. L. No. 106-386, 114 Stat. 1466-68 (2000); see also 18 U.S.C. § 1589 (2000) (stating that the procurement of human 
(DOL) similarly failed to find any substantial violations of law, ${ }^{10}$ although the employer had failed to recognize the most basic employment rights, such as the worker's ability to control his earnings, seek medical care, or work in an environment free of retaliation. ${ }^{11}$ Each year, employers bring over two hundred thousand guest workers $^{12}$ on $\mathrm{H}-2 \mathrm{~A}$ and $\mathrm{H}-2 \mathrm{~B}$ visas to work in the United States in temporary nonprofessional jobs. ${ }^{13}$ Despite the well-known and documented abuses within the guest worker program, ${ }^{14}$ the government has, for the most part, failed to curb such abuses. ${ }^{15}$ This

labor through threats, deceitful schemes, or abuses of the legal system is punishable by imprisonment or fines); H.R. REP. NO. 106-939, at 101 (2000) (Conf. Rep.) ("Because provisions within section 1589 only require a showing of a threat of 'serious harm,' or of a scheme, plan, or pattern intended to cause a person to believe that such harm would occur, federal prosecutors will not have to demonstrate physical harm or threats of force against victims.").

10. Letter from Cynthia Watson, Disclosure Officer, U.S. Dep't of Labor, to author (Dec. 1, 2011) (on file with author).

11. The H-2A regulations in effect provided that workers (1) should receive their pay; (2) should be covered by workers' compensation insurance; and (3) should not be retaliated against for having raised their rights under the H-2A regulations. 20 C.F.R. $\S \S 655.102(b)(2),(9),(10)$, $655.103(\mathrm{~g})$ (1988). As provided, the H-2A regulations neither explicitly prohibited a worker from receiving his pay in a bank account nor required an employer to assist a worker in seeking medical care.

12. "Guest worker" refers to an immigrant worker who is present on temporary nonimmigrant visas, such as an "unskilled" worker who receives an H-2A or H-2B visa. 8 U.S.C. $\S 1101(\mathrm{a})(15)(\mathrm{H})(\mathrm{i})(2006)$. The term has been criticized because it is considered a "euphemism for the status and condition of workers." Mary Lee Hall, Defending the Rights of $\mathrm{H}-2 \mathrm{~A}$ Farmworkers, 27 N.C. J. INT'L L. \& COM. REG. 521, 522 (2002). This Article will use the term guest worker to refer exclusively to workers with $\mathrm{H}-2 \mathrm{~A}$ or $\mathrm{H}-2 \mathrm{~B}$ visas.

13. RANDAll MONGER \& MEgan Mathews, DeP'T OF Homeland SEC., NonimMigrant ADMISSIONS TO THE UNITED STATES: 20105 (2011), available at http://www.dhs.gov/xlibrary /assets/statistics/publications/ni_fr_2010.pdf.

14. FarmWOrker Justice, No Way to Treat a GUESt: Why the H-2A Agricultural Visa Program Fails U.S. AND Foreign Workers 30-31 (2011); S. POVERTy LaW Ctr., Close to Slavery: GuestWorker Programs IN THE UNITED STATES 16-17 (2007).

15. While the government touts new efforts to combat workplace violations against guest workers, government policies continue to play a substantial role in sanctioning the exploitation of guest workers. Maria L. Ontiveros, Noncitizen Immigrant Labor and the Thirteenth Amendment: Challenging Guest Worker Programs, 38 U. TOL. L. REV. 923, 938-39 (2007). The federal government recently overhauled the regulations for both the $\mathrm{H}-2 \mathrm{~A}$ and $\mathrm{H}-2 \mathrm{~B}$ programs. Temporary Non-Agricultural Employment of H-2B Aliens in the United States, 77 Fed. Reg. 10038 (Feb. 21, 2012) (codified at 20 C.F.R. pt. 655); Temporary Agricultural Employment of H2A Aliens in the United States, 75 Fed. Reg. 6884 (Feb. 12, 2010) (codified at 20 C.F.R. pt. 655). At the time of writing, the revised $\mathrm{H}-2 \mathrm{~B}$ regulations never went into effect because they were enjoined by Bayou Lawn \& Landscape Servs. v. Hilda Solis, No. 12-cv-183-MCR/CJK, 2012 U.S. Dist. LEXIS 69297 (N.D. Fla. Apr. 26, 2012) (order granting preliminary injunction). The new regulations address some of the problems within these programs; however, they fail to correct the underlying flaw of the program, which provides a temporary visa that is tied to a specific employer. See, e.g., Michael J. Wishnie, Labor Law After Legalization, 92 MiNN. L. REV. 
failure to protect guest workers reflects the government's more general ambivalence toward workplace exploitation of immigrant workers, ${ }^{16}$ which is symbolic of the general neglect of the working class, ${ }^{17}$ the powerful economic interests of the businesses that rely on such exploitation, ${ }^{18}$ and the political weakness of immigrants who

1446, 1455 (2008) (citing the lack of portability or a path to legalized status as being crucial to address guest worker exploitation). See infra Part I for further discussion.

16. Hiroshi Motomura, The Rights of Others: Legal Claims and Immigration Outside the Law, 59 DUKE L.J. 1723, 1726 (2010) (discussing the "national ambivalence about immigration outside the law" where unauthorized migrants are permitted to assert their rights indirectly or obliquely within the legal system). The U.S. Department of Labor, for example, has recently launched a "We Can Help" campaign to inform workers of their rights and encourage them, regardless of their immigration status, to report violations of wage and hour laws on the job. Press Release, U.S. Dep't of Labor, US Labor Secretary Sends Message to America's Under-Paid and Under-Protected: 'We Can Help!' (Apr. 1, 2010), http://www.dol.gov/opa/media/press/whd /WHD20100411.htm. On the other hand, the federal government is still conducting workplace raids that further drive workers underground and contribute to worker exploitation. Bill Ong Hing, One Hand Clapping for Latest Obama Deportation Reforms, HuFFINGTON POST (Aug. 23, 2011, 6:28 PM), http://www.huffingtonpost.com/bill-ong-hing/one-hand-clapping-for -lat_b_932646.html; see also Jennifer M. Chacón, Tensions and Trade-Offs: Protecting Trafficking Victims in the Era of Immigration Enforcement, 158 U. PA. L. REV. 1609, 1615 (2010) (arguing that antitrafficking efforts have been heavily constrained by the policies of rigid immigration enforcement); Juliet Stumpf \& Bruce Friedman, Advancing Civil Rights Through Immigration Law: One Step Forward, Two Steps Back?, 6 N.Y.U. J. LeGIS. \& PUB. POL'Y 131, 132 (2002) (highlighting the tension between governmental laws relating to immigration enforcement and civil rights).

17. Annette Bernhardt et al., An Introduction to the "Gloves-off Economy," in THE GLOVESOFF ECONOMY: WORKPLACE STANDARDS AT THE BOTTOM OF THE AMERICAN LABOR MARKET 1, 16-18 (Annette Bernhardt et al. eds., 2008) (describing how the decline in government enforcement from 1975 to present has negatively impacted low-wage workers); Karl E. Klare, Toward New Strategies for Low-Wage Workers, 4 B.U. PUB. INT. L.J. 245, 259 (1995) ("[T]he United States has chosen a legal regime that not only tolerates but in some ways actively encourages low-wage work and the persistence of extreme poverty."); Frank W. Munger, Social Citizen as "Guest Worker": A Comment on Identities of Immigrants and the Working Poor, 49 N.Y.L. SCH. L. REV. 665, 672-73 (2004) (noting how policies that have reduced regulation and downsized the welfare state have resulted in the convergence between immigrants and the indigenous working poor in their exclusion from social citizenship); Rebecca Smith, Human Rights at Home: Human Rights as an Organizing and Legal Tool in Low-Wage Worker Communities, 3 STAN. J. C.R. \& C.L. 285, 288-89 (2007) (discussing how core standards to address the lack of bargaining power of low-wage workers have been neglected).

18. Ruben J. Garcia, Ghost Workers in an Interconnected World: Going Beyond the Dichotomies of Domestic Immigration and Labor Laws, 36 U. MICH. J.L. REFORM 737, 756-57 (2003); Beth Lyon, When More "Security" Equals Less Workplace Safety: Reconsidering U.S. Laws that Disadvantage Unauthorized Workers, 6 U. PA. J. LAB. \& EMP. L. 571, 594 (2004); Cristina M. Rodriguez, The Significance of the Local in Immigration Regulation, $106 \mathrm{MICH}$. L. REV. 567, 590 (2008); Stumpf \& Friedman, supra note 16, at 145. 
are essentially excluded from meaningful membership to our society. ${ }^{19}$

At the same time that the government has failed to avail itself of affirmative investigative initiatives at its disposal, it has authorized private civil remedies that can be invoked by immigrant workers. The federal government's failure to protect workers, and its creation of these private civil remedies, presents an implicit devolution of rights from the federal government to individual workers. ${ }^{20}$ The TVPA created not only immigration remedies for victims of a severe form of human trafficking but also a private right of action for violations of peonage, slavery, and human trafficking crimes. ${ }^{21}$ The Violence Against Women Act of 2000 created U visas for crime victims, ${ }^{22}$ which advocates are increasingly using to address

19. Ruben J. Garcia, Labor as Property: Guestworkers, International Trade, and the Democracy Deficit, 10 J. GENDER RACE \& JUST. 27, 43-45 (2006) (noting that immigrant guest workers have limited ability to influence legislation relating to the workplaces that are heavily regulated by the government); Kevin R. Johnson, Hurricane Katrina: Lessons About Immigrants in the Administrative State, 45 Hous. L. REV. 11, 43-44 (2008) (describing how immigrants lack a full voice in the political system that administers their rights); Munger, supra note 17, at 674-75 (arguing that both immigrants and the working poor are disenfranchised by the political process); Juliet Stumpf, The Crimmigration Crisis: Immigrants, Crime, and Sovereign Power, 56 AM. U. L. REV. 367, 400-02 (2006) (describing that the immigration laws presume nonmembership of immigrants who are otherwise subject to a sliding scale of rights within the United States).

20. The perceived failure of the federal government to adequately address immigration issues, for example, has led to the devolution of federal immigration powers to the state and local governments. Keith Cunningham-Parmeter, Forced Federalism: States as Laboratories of Immigration Reform, 62 HASTINGS L.J. 1673, 1674 (2011) ("The states, displeased with decades of lax enforcement at the federal level, have taken immigration matters into their own hands."); Clare Huntington, The Constitutional Dimension of Immigration Federalism, 61 VAND. L. REV. 787, 805-06 (2008) (noting that local lawmakers "have expressed frustration with enforcement failures at the national level and thus see a need to take their own action"); Rodriguez, supra note 18, at 590-91 (arguing that the inability to achieve a comprehensive national policy is reflected in the diverse local laws that have arisen to address unauthorized immigration).

21. William Wilberforce Trafficking Victims Protection Reauthorization Act of 2008, Pub. L. No. 110-457, 122 Stat. 5044 (2008); Trafficking Victims Protection Reauthorization Act of 2005, Pub. L. No. 109-164, 119 Stat. 3558 (2005); Trafficking Victims Protection Reauthorization Act of 2003, Pub. L. No. 108-193, 117 Stat. 2875 (2003); Victims of Trafficking and Violence Protection Act of 2000, Pub. L. No. 106-386, 114 Stat. 1464 (2000).

22. Violence Against Women and Department of Justice Reauthorization Act of 2005Technical Corrections, Pub. L. No. 109-271, 120 Stat. 750 (2006) (incorporating technical corrections to the Violence Against Women and Department of Justice Reauthorization Act of 2005); Violence Against Women and Department of Justice Reauthorization Act of 2005, Pub. L. No. 109-164, 119 Stat. 2960 (2006); Violence Against Women Act of 2000, Pub. L. No. 106-386, 114 Stat. 1464, 1533-37 (2000). The Violence Against Women Act of 2000 is Division B of the Victims of Trafficking and Violence Protection Act of 2000. 
workplace crimes. ${ }^{23}$ The private right of action under the Racketeer Influenced and Corrupt Organizations Act (RICO) can be used against employers for criminal exploitation in the workplace. ${ }^{24}$ Organizers around the country are using local, state, and federal laws to address wage theft. ${ }^{25}$ Increasingly, immigrant workers are using antidiscrimination laws to characterize their employer's criminal conduct against them as a form of racial or national origin discrimination. ${ }^{26}$ Notably, a governmental impetus to combat crime is behind many of these opportunities for private civil remedies.

Many commentators have noted the failure of the government to address the exploitation of immigrants ${ }^{27}$ and have correspondingly advocated for a reformulation of governmental practices and

23. NAT'L EMP'T LAW PROJECT, THE U VISA: HOW CAN It PROTECT IMMIGRANT WORKERS? (Aug. 03, 2012), available at http://www.nelp.org/page/-/Justice/2012/UvisaFlyer EnglishSpanish.pdf?nocdn=1; Memorandum from Naomi C. Earp, Chair, U.S. Equal Emp't Opportunity Comm'n, to Dist. Dirs. and Reg'l Attorneys (July 3, 2008), available at http:// iwp.legalmomentum.org/immigration/u-visa/government-memoranda-and-factsheets/U\%20VISA _EEOC\%20Certification\%20Memo_7.3.08.pdf; Memorandum from Nancy J. Leppink, Acting Adm'r, U.S. Dep't of Labor, to Reg'l Admins. and Dist. Dirs. (Apr. 28, 2011), available at http://www.dol.gov/whd/FieldBulletins/fab2011_1.pdf.

24. Racketeer Influenced and Corrupt Organizations Act, Title IX of the Organized Crime Control Act of 1970, Pub. L. No. 91-452, 84 Stat. 941 (1970).

25. Nik Theodore, Univ. of Ill. At Chi., The Movement to End Wage Theft: A REPORT TO THE DISCOUNT FOUNDATION 10-12, 16-17 (Oct. 2011), available at http://www.discountfoundation.org/sites/all/files/Wage Theft Report 2011 Oct.pdf.

26. Lilly Ledbetter Fair Pay Act of 2009, Pub. L. No. 111-2, 123 Stat. 5 (2009); Civil Rights Act of 1991, Pub. L. No. 102-166, 105 Stat. 1071 (1991); Title VII of the Civil Rights Act of 1964, Pub. L. No. 88-352, 78 Stat. 241 (1964); Civil Rights Act of 1866 (codified as amended at 42 U.S.C. $\S \S 1981-1982(1982))$.

27. Commentators, for example, have criticized the failure of the federal government to act as a watchdog over immigrant workers generally, see, for example, Rebecca Smith \& Catherine Ruckelshaus, Solutions, Not Scapegoats: Abating Sweatshop Conditions for All Low-Wage Workers as a Centerpiece of Immigration Reform, 10 N.Y.U. J. LEGIS. \& PUB. POL'Y 555, 55964 (2007), and more specifically with respect to guest workers, see, for example, Andrew J. Elmore, Egalitarianism and Exclusion: U.S. Guest Worker Programs and a Non-Subordination Approach to the Labor-Based Admission of Nonprofessional Foreign Nationals, 21 GEO. IMMIGR. L.J. 521, 553 (2007); Michael Holley, Disadvantaged by Design: How the Law Inhibits Agricultural Guest Workers from Enforcing Their Rights, 18 HOFSTRA LAB. \& EMP. L.J. 575, 598-604 (2001). Others have criticized the government's failure to prosecute cases against employers for the criminal exploitation of workers. See, e.g., Jennifer M. Chacón, Misery and Myopia: Understanding the Failures of U.S. Efforts to Stop Human Trafficking, 74 FORDHAM L. REV. 2977, 3032-33 (2006); Grace Chang \& Kathleen Kim, Reconceptualizing Approaches to Human Trafficking: New Directions and Perspectives from the Field(s), 3 STAN. J. C.R. \& C.L. 317, 324-25 (2007). 
policies, ${ }^{28}$ which includes ameliorating the political condition of immigrant workers. ${ }^{29}$ This Article takes a distinct approach by examining whether private civil remedies, initiated by the individual worker, can provide a viable alternative for immigrant workers facing exploitation. Given the availability of such remedies, it is worth analyzing whether there may be positive attributes found in this devolution of rights. ${ }^{30}$ Private civil remedies can serve as a more immediate tool to address the inherently flawed system that engenders workplace exploitation of immigrant workers. ${ }^{31}$ Because immigrant workers are severely disadvantaged in the political arena, the use of private civil remedies becomes a means by which to address their social and economic rights. ${ }^{32}$

28. See, e.g., Chacón, supra note 27, at 3040; Elmore, supra note 27, at 562-65; Holley, supra note 27, at 616-17; Smith \& Ruckleshaus, supra note 27, at 582-600.

29. Elmore, supra note 27 , at 562 . Some scholars have generally explored prescriptive solutions to improve the political condition of immigrant workers. See, e.g., Jennifer Gordon, Transnational Labor Citizenship, 80 S. CAL. L. REV. 503, 565 (2007) (proposing transnational labor citizenship that correspondingly crosses borders); D. Carolina Nunez, Fractured Membership: Deconstructing Territoriality to Secure Rights and Remedies for the Undocumented Worker, 2010 WIS. L. REV. 817, 870 (2010) (arguing that immigrant workers are members of the employment sphere entitled to the full distribution of membership rights available in that sphere); Cristina M. Rodriguez, Guest Workers and Integration: Toward a Theory of What Immigrants and Americans Owe One Another, 2007 U. CHI. LEGAL F. 219, 278 (2007) (proposing substantially expanded opportunities for permanent membership of immigrants by expanding the number of LPR visas available to unskilled immigrants).

30. This concept is derived from the literature that has examined the positives arising from the devolution of federal immigration powers to local governments. See, e.g., Rodriguez, supra note 18, at 617; Peter H. Schuck, Taking Immigration Federalism Seriously, 2007 U. CHI. LEGAL F. 57, 59 (2007); Rick Su, A Localist Reading of Local Immigration Regulations, 86 N.C. L. REV. 1619, 1623-24 (2008).

31. See, e.g., Kathleen Kim, The Trafficked Worker as Private Attorney General: A Model for Enforcing the Civil Rights of Undocumented Workers, 2009 U. CHI. LEGAL F. 247 (2009) (demonstrating that trafficked workers can act as private attorney generals to enforce civil rights violations against their unscrupulous employers); Leticia M. Saucedo, A New "U”: Organizing Victims and Protecting Immigrant Workers, 42 U. RICH. L. REV. 891 (2008) (arguing that immigrant workers can use $U$ visas as a rights-conferring device for victims of labor exploitation and as a tool for collective workplace change); see also Beth Lyon, Tipping the Balance: Why Courts Should Look to International and Foreign Law on Unauthorized Immigrant Worker Rights, 29 U. PA. J. INT'L L. 169, 230-31 (2007) (arguing that immigrant workers should utilize remedies that apply international human right norms).

32. Some legal scholarship has forcefully expressed skepticism about the use of the law, much less legal remedies, to create meaningful social change. See, e.g., Derrick A. Bell, Jr., Serving Two Masters: Integration Ideals and Client Interests in School Desegregation Litigation, 85 YALE L.J. 470, 513 (1976); see also Scott L. Cummings \& Ingrid V. Eagly, A Critical Reflection on Law and Organizing, 48 UCLA L. REV. 443, 451-53 (2001) (providing a brief review of progressive legal scholarship and its skepticism toward law as a vehicle for social change). The use of the judicial system still remains, however, an accessible, if not important, 
By using the lens of the guest worker program, this Article examines to what end the devolution of rights via private civil remedies can be leveraged to benefit immigrant workers. With the rather dismal picture of government inaction, it is not surprising that advocates have been particularly motivated to consider the use of private civil remedies to address the recurring dilemmas within the guest worker system. Guest workers, like the H-2A cattle herders, have used such remedies to seek redress for their criminal exploitation. ${ }^{33}$ Private civil remedies create worker agency because workers can vindicate their rights without having to rely on governmental institutions that have historically failed to enforce workplace violations of the law. These remedies also give workers the opportunity to counter the characterization of being passive victims who otherwise can only be assisted "by the largesse of the benign state." ${ }^{34}$ Even when private civil remedies provide for mixed results, workers still participate in reshaping the boundaries of the law and produce counternarratives that can confer legitimacy on a movement's claims. ${ }^{35}$ By placing the employer's conduct into the broader context of criminal exploitation of all workers, these

avenue for the politically powerless to bring about justice. Scott L. Cummings, Litigation at Work: Defending Day Labor in Los Angeles, 58 UCLA L. REV. 1617, 1621 (2011) (finding that the underlying conditions point in favor of a litigation-based approach for day laborers in Los Angeles, not only because these day laborers are politically weak, but also because they possess a strong legal right to solicit work in public that, if protected, is self-enforcing); Keith Cunningham-Parmeter, Redefining the Rights of Undocumented Workers, 58 AM. U. L. REV. 1361, 1405 (2009) ("II]n some instances, the so called 'individual rights' afforded by wage and antidiscrimination statutes can be more effective vehicles for achieving collective ends than traditional labor law currently allows"); Kati L. Griffith, U.S. Migrant Worker Law: The Interstices of Immigration Law and Labor and Employment Law, 31 COMP. LAB. L. \& POL'Y J. 125,160 (2009) ("The promotion of private attorneys general and the protection of collective action are central to workplace law regulation"); see generally Deborah M. Weissman, Law as Largess: Shifting Paradigms of Law for the Poor, 44 WM. \& MARY L. REV. 737, 750 (2002) ("In a larger sense, the judicial system is the primary setting to challenge social conditions that bear oppressively on those without means.").

33. Johnson, supra note 1; see also infra notes 195-199 and accompanying text (providing a further discussion of this lawsuit).

34. Leti Volpp, Migrating Identities: On Labor, Culture, and Law, 27 N.C. J. INT'L L. \& COM. REG. 507, 509 (2002).

35. Cummings, supra note 32 , at 1622-23. 
remedies can help reframe the debate and counter negative cultural assumptions about immigrant workers. ${ }^{36}$

To begin this analysis, Part I gives a brief background on the inherent nature of exploitation within guest worker programs and the failure of the federal government to act as a watchdog over this exploitation in both the civil and criminal arenas.

Part II explores how the lack of government action has led to the devolving use of private civil remedies to redress guest worker exploitation by focusing on three specific examples. In particular, it examines how the private right of action under the TVPA and RICO, as well as the use of antidiscrimination laws, are particularly well suited to address the egregious abuses that arise out of a flawed guest worker system. This Part also considers how the use of such remedies has advanced the conceptual framework of these laws to encompass multiple forms of exploitation.

Part III examines how this devolution of rights can lead to guest worker empowerment, but it also reviews the fundamental constraints associated with asserting these rights in a judicial forum. Private civil remedies bestow workers with agency and can be extended to immigrant workers who work without authorization. Immigrant workers, however, legitimately fear reporting workplace exploitation, so the use of such remedies must necessarily be integrated with other measures, such as outreach and educational efforts, crime-related victim visas, litigation tools to protect client identity and immigration status, and the support of community-based organizations. A delicate balance is also required so that private civil remedies do not operate contrary to collective efforts for social change. Rather, by producing important counternarratives that can ultimately influence the public debate, they should be used in concert with organizing, education, and policy reform. Taken with these constraints, then, Part III concludes that private civil remedies are worth considering as a significant strategy for advancing guest worker rights.

36. Cunningham-Parmeter, supra note 32, at 1402 (arguing that enforcement of wage and antidiscrimination rights "constitutes collective action that ensures better working conditions for immigrants and citizens alike"). 


\section{BACKGROUND}

Guest workers can come to the United States to work for a temporary period of time, usually less than one year, with an $\mathrm{H}-2 \mathrm{~A}$ or $\mathrm{H}-2 \mathrm{~B}$ visa. $\mathrm{H}-2 \mathrm{~A}$ visas are for agricultural jobs, ${ }^{37}$ while $\mathrm{H}-2 \mathrm{~B}$ visas are for nonagricultural jobs, ${ }^{38}$ such as those in the landscaping, forestry, hospitality, and seafood industries. ${ }^{39}$ Under these visa programs, employers may bring foreign workers from abroad for a temporary time period, if the employers are able to prove that no U.S. workers are available for the job. ${ }^{40}$ As part of this process, employers are required to submit labor-certification applications to the DOL, certifying that they have recruited U.S. workers for the specified job positions. ${ }^{41}$ Only after receiving an approved DOL labor certification may employers then apply for the visas with the Department of Homeland Security (DHS) and actually bring workers to the United States. ${ }^{42}$

\section{A. Guest Worker Programs Facilitate Labor Abuses}

As one worker advocate has astutely observed, "guest workers are not free and have no rights of membership in society." 43 Guest

37. 20 C.F.R. $§ 655.103$ (c) (2012) (defining H-2A program for workers in agricultural labor or services).

38. 20 C.F.R. $\S 655.6$ (a) (2012) (defining the H-2B program for workers in occupations other than agriculture or nursing).

39. See Jayesh M. Rathod, A Season of Change: Reforming the H-2B Guest Worker Program, CleARINGHOUSE REV., May-Jun. 2011, at 20 (explaining how nonagricultural jobs are supported by thousands of temporary guest workers with H-2B visas); Arthur N. Read, Learning from the Past: Designing Effective Worker Protections for Comprehensive Immigration Reform, 16 TEMP. POL. \& CIV. RTS. L. REV. 423, 432 (2007) (giving an overview of the H-2B temporary non-agricultural worker program); Smith \& Ruckelshaus, supra note 27, at 577 (same).

40. 20 C.F.R. $\S \S 655.135,655.40$ (2012).

41. Id. $\S \S 655.150-.162,655.15$.

42. 8 C.F.R. $\S 214.2(\mathrm{~h})(5)-(6)(2012)$.

43. Hall, supra note 12 , at 527 . The guest worker programs have spawned a great deal of criticism because guest workers are extremely vulnerable to abuse. See generally Bryce W. Ashby, Note, Indentured Guests-How the H-2A and H-2B Temporary Guest Worker Programs Create the Conditions for Indentured Servitude and Why Upfront Reimbursement for Guest Workers' Transportation, Visa, and Recruitment Costs Is the Solution, 38 U. MEM. L. REV. 893, 895 (2008) (comparing guest worker conditions to indentured servitude); Elmore, supra note 27, at 521 (noting that there has been sharp disagreement about whether it is wise to expand laborbased admissions); Victoria Gavito, The Pursuit of Justice Is Without Borders: Binational Strategies for Defending Migrants' Rights, HUM. RTS. BRIEF Spring 2007, at 5, 5 (2007) (noting immigrants' fear "factors as a barrier to justice"); Griffith, supra note 32, at 126 (noting that 
worker programs tie a worker's temporary visa to a single employer, ${ }^{44}$ so that the employer maintains total control over the worker. The employer "dictates the terms and conditions of the contract, terminates the guest worker at will, and determines whether to extend the work relationship." 45 Further, since $\mathrm{H}-2$ visas are temporary and do not provide a path to lawful permanent residency, guest workers are a de facto underclass of immigrant workers who lack the benefits that come with integrating into U.S. society. ${ }^{46}$

The inherent imbalance of power that exists between guest workers and employers keeps workers silent in the face of abusive

immigrant workers are currently the subject of debate and that new studies depict how low-wage migrant workers suffer severe mistreatment); Lisa Guerra, Note, Modern-Day Servitude: A Look at the H-2A Program's Purposes, Regulations, and Realities, 29 VT. L. REV. 185, 186 (2004) (comparing H-2A abuses to those suffered by slaves in the early 1600s); Sovereign Hager, Note, Farm Workers and Forced Labor: Why Including Agricultural Guest Workers in the Migrant and Seasonal Worker Protection Act Prevents Human Trafficking, 38 SYRACUSE J. INT’L. L. \& COM. 173, 173 (2010) (arguing that the H-2A guest worker programs make farm workers especially vulnerable to human trafficking); Dorothy E. Hill, Guest Worker Programs Are No Fix for Our Broken Immigration System: Evidence from the Northern Mariana Islands, 41 N.M. L. REV. 131, 152-55 (2011) (blaming H-2 workers' failure to vindicate their rights on government oversight and lack of accessible avenues for worker complaints); Holley, supra note 27, at 577 (proposing that $\mathrm{H}-2 \mathrm{~A}$ workers are desirable to employers because they are especially vulnerable); Elizabeth Johnston, Note, The United States Guest Worker Program: The Need for Reform, 43 VAND. J. TRANSNAT'L L. 1121, 1121 (2010) (describing abuse of workers); Maria L. Ontiveros, Noncitizen Immigrant Labor and the Thirteenth Amendment: Challenging Guest Worker Programs, $38 \mathrm{U}$. TOL. L. REV. 923, 923 (2007) (labeling immigration as a current "hot-button issue"); Rodriguez, supra note 29, at 219 (claiming that the presence of unauthorized immigrants has generated a charged debate over the need to overhaul immigration laws).

44. Hall, supra note 12, at 529; Rathod, supra note 39, at 22.

45. Elmore, supra note 27 , at 535. The special subset of H-2A workers who herd sheep, goats, or cattle, for example, are entirely dependent on their employer for food, water, and communication with the outside world. Jennifer J. Lee, The Sheepherder Project: Devising Systemic Change for Marginalized Workers, ClEARINGHOUSE REV. Mar.-Apr. 2012; see also Training and Employment Guidance Letter No. 32-10: Special Procedures: Labor Certification Process for Employers Engaged in Sheepherding and Goatherding Occupations Under the H-2A Program, 76 Fed. Reg. 47256 (Aug. 4, 2011) (providing special procedures for employers hiring H-2A workers to herd sheep and goats); Advisory from Jane Oates, Assistant Secretary, Emp't \& Training Admin., U.S. Dep't of Labor, to Chi. Nat'l Processing Ctr. Program Dir. State Workforce Agency Admins. (June 14, 2011) (regarding special procedures for employers "who apply to the Department of Labor ... to obtain labor certification to hire temporary agricultural foreign workers in occupations involved in the open range production of livestock in the United States").

46. Ontiveros, supra note 43, at 938 (stating that guest worker visas limit the ability of workers to participate fully in U.S. society); Rodriguez, supra note 29, at 222 (finding that guest worker programs impose bureaucratic requirements that constrain immigrant mobility in the economy and therefore in society at large). The isolation of these workers erects additional barriers that prevent them from addressing abuses. Elmore, supra note 27, at 552; Holley, supra note 27 , at $594-95$. 
working conditions. Guest workers fear retaliation by employers, which can include deportation, blacklisting, and denial of rehiring for the following season. ${ }^{47}$ This climate of fear can be created by the employers' explicit threats to call DHS, the existence of a blacklist, or even the mere fact that the employer holds the "deportation card." 48 The North Carolina Growers' Association, for example, maintained a blacklist of $\mathrm{H}-2 \mathrm{~A}$ workers who were barred from rehire for the following season because they had complained about job conditions, such as the inability to access drinking water in the fields. $^{49}$

Guest workers may also fear voicing complaints if they arrive in the United States with significant debt. Unscrupulous recruiters can charge workers for travel, visa, and recruitment costs. ${ }^{50}$ In one case, H-2A workers from Thailand were charged tens of thousands of dollars and required to take out risky loans and mortgage family farmland to pay recruitment costs. ${ }^{51}$ Despite labor abuses, arriving in the United States in debt motivates workers to remain on the job because quitting is not a viable option. ${ }^{52}$

As a result, employers can exploit guest workers more readily than native low-wage workers. Reported abuses include the confiscation of documents, wage and hour violations, neglect of onthe-job injuries, unsafe and unhealthy housing conditions, verbal and physical abuse, and sexual violence. ${ }^{53}$ Guest workers with significant recruitment debt become susceptible to debt bondage and forced

47. Elmore, supra note 27, at 542; Holley, supra note 27, at 596-97; Read, supra note 39, at $430-31$.

48. S. POVERTY LAW CTR., supra note 14, at 15; Hall, supra note 12, at 533.

49. David Bacon, Be Our Guests, NATiOn, Sept. 27, 2004, at 23.

50. S. POVERTY LAW CTR., supra note 14, at 9-14; Gavito, supra note 43, at 5; Holley, supra note 27 , at 596 . The recently revised $\mathrm{H}-2 \mathrm{~A}$ regulations, which prohibit such charges, still permit this practice to flourish as employers can simply turn a blind eye. FARMWORKER JUSTICE, supra note 14 , at 22.

51. John Bowe, Bound for America, MOTHER JONES, May-June 2010, at 61, 65.

52. Griffith, supra note 32, at 137; Holley, supra note 27, at 596.

53. See, e.g., Am. Univ. Wash. Coll. of LaW \& Centro de los Derechos del Migrante, InC., Picked Apart: The Hidden Struggles of Migrant Worker Women in the MARYland CRAB Industry 2-3 (2010); Colo. Legal SERVS., OverWORKED AND UNDERPAID: H-2A HERDERS IN COLORADO 12-19 (2010); FARMWORKER JUSTICE, supra note 14, at 22-33, 35; S. POVERTY LAW CTR., supra note 14, at 2; U.S. GOV'T ACCOUNTABILITY OfFice, Closed Civil and CRiminal CASEs Illustrate Instances of H-2B Workers BEING TARGETS OF FRAUD AND ABUSE (2010). 
labor. ${ }^{54}$ Abuses, such as the confiscation of documents, intimidation, and threats, can be connected to human trafficking. ${ }^{55}$ As long as the underlying structural flaw of guest worker programs remains intacthaving workers tied to a single employer by a temporary visaworkers will lack free choice and the abuses will continue. ${ }^{56}$

\section{B. Government Enforcement Is Inadequate}

Multiple government agencies could play a role in addressing the exploitation of guest workers. The reality, however, is that government oversight has largely failed to provide protection for guest workers.

The DOL oversees the regulatory scheme designed to ensure that the employment of $\mathrm{H}-2$ workers does not adversely affect the compensation and working conditions of U.S. workers. ${ }^{57}$ The Wage and Hour Division (WHD) of the DOL is authorized to enforce the terms and conditions of H-2 workers' employment to ensure compliance with the regulations. ${ }^{58}$ The Employment and Training Administration (ETA) of the DOL oversees employer participation in the $\mathrm{H}-2$ program by approving labor certifications for employers that can show that they comply with the program requirements. ${ }^{59}$

The DOL regulatory framework that purportedly protects guest workers has remained largely theoretical and has failed to address workplace abuses. ${ }^{60}$ The Obama Administration recently revamped the regulations applicable to guest worker programs. ${ }^{61}$ The

54. FARMWORKER JUSTICE, supra note 14, at 23; Elmore, supra note 27, at 536-38.

55. FARMWORKER JUSTICE, supra note 14, at 22-23; S. POVERTY LAW CTR., supra note 14, at 38-39; Britta S. Loftus, Coordinating U.S. Law on Immigration and Human Trafficking: Lifting the Lamp to Victims, 43 COLUM. HUM. RTS. L. REV. 143, 178 (2011).

56. Elmore, supra note 27, at 561; Wishnie, supra note 15, at 1455.

57. 20 C.F.R. $\S \S 655.100-.185,655.1-.81$ (2012).

58. 29 C.F.R. $\S 501.0-.9,(2011) ; 20$ C.F.R. $\S 655.2(a)$.

59. 20 C.F.R. $\S \S 655.130-.135,655.2($ b) (2012).

60. Elmore, supra note 27, at 545-46 (referring to guest worker rights as "illusory"); Garcia, supra note 19, at 51 (recognizing that abuses continue to exist despite the existence of strong worker protections on paper); Rathod, supra note 39 , at 22 (discussing how H-2B regulatory changes fail to remedy the "core structural flaw" of portability of visas); Read, supra note 39, at 429 (referring to H-2A rights as "theoretical").

61. See supra note 15 and accompanying text. Such regulations may be subject to change depending on the politics of the incoming administration. In 2008, for example, the Bush Administration enacted regulations for the $\mathrm{H}-2 \mathrm{~A}$ program that greatly disfavored workers. Temporary Agricultural Employment of H-2A Aliens in the United States, 73 Fed. Reg. 77110 
regulations outline specific standards, such as those related to pay and deductions, ${ }^{62}$ as well as more general requirements, such as the requirement that employers to "comply with all applicable Federal, State and local laws and regulations, including health and safety laws." 63 While certain aspects of the revised regulations provide for higher standards for workers, ${ }^{64}$ the regulatory framework, especially with its more generalized requirements, still fails to give any specific hook for addressing the most egregious conduct of employers, such as intimidation, denial of medical care, and verbal and physical abuse. ${ }^{65}$ Further, the regulations say "absolutely nothing about when or in what manner the agency must act." 66 Nor is there any affirmative requirement in the code that requires regular investigations or audits by WHD. ${ }^{67}$ The regulations also fail to contemplate the practical reality that governmental offices are

(Dec. 18, 2008); Modernizing the Labor Certification Process and Enforcement, 73 Fed. Reg. 77110 (Dec. 18, 2008) (codified at 20 C.F.R. pt. 655). In 2008, the Obama Administration suspended those regulations. Temporary Employment of H-2A Aliens in the United States, 74 Fed. Reg. 11408 (proposed Mar. 17, 2009) (to be codified at 20 C.F.R. pt. 655). Subsequently, a large group of growers sued the Obama Administration for having violated the Administrative Procedures Act, and a federal court granted a preliminary injunction. N.C. Growers' Ass'n, Inc. v. Solis, 644 F. Supp. 2d 664, 667-68 (M.D.N.C. 2009). Growers have engaged in a campaign "to eliminate or weaken job protections, government oversight, and enforcement mechanisms under the H-2A program." FARMWORKER JUSTICE, supra note 14, at 37; see, e.g., HARVEST Act, S. 1384, 112th Cong. (2011).

62. 20 C.F.R. $\S \S 655.122(j)-(m),(p), 655.20(a)-(c)(2012)$.

63. Id. §655.135(e); accord id. $\S 655.20(\mathrm{z})$ ("[T]he employer must comply with all applicable Federal, State and local employment-related laws and regulations, including health and safety laws.").

64. The proposed $\mathrm{H}-2 \mathrm{~B}$ regulations raise the standards to make them more analogous to the H-2A program. Rathod, supra note 39 , at 23-25.

65. The regulations contain no explicit protections from this kind of behavior, except for the extremely limited provision that prohibits retaliation after a worker has "exercised or asserted" any right or protection afforded by the H-2A regulations. 20 C.F.R. $\S \S 655.135(\mathrm{~h})(5)$, 655.20(n)(5); see also FARMWORKER JUSTICE, supra note 14, at 15-16 (reviewing how the theoretical worker protections in the revised H-2A regulations do not apply to protect workers in practice); Lee, supra note 45 (discussing how the H-2A regulations do not address common abuses such as verbal abuse or lack of breaks).

66. Holley, supra note 27, at 601 (explaining how the H-2A regulations provide no timeline for workers' complaints in comparison to the strict timelines related to provisions that apply to employers).

67. It is noteworthy that the $\mathrm{H}-2 \mathrm{~B}$ regulations require regular audits by ETA as to the certification applications, but not as to actual workplace conditions. 20 C.F.R. $\S 655.70$ (2011). 
inaccessible to guest workers hoping to use the complaint procedure. $^{68}$

Apart from these structural inadequacies, WHD largely fails to pursue guest worker complaints because of a lack of will and resources. ${ }^{69}$ This is evident in the lack of affirmative oversight and irregular inspection of employer worksites. ${ }^{70}$ In 2004 , for example, WHD investigated eighty-nine H-2A employers out of the thousands that participate in the program. ${ }^{71}$ When WHD does carry out an investigation, it overwhelmingly fails to find meaningful violations or redress for workers, or it favors finding violations that can only be substantiated on paper. ${ }^{72}$ A 2009 report by the U.S. Government Accountability Office confirmed what guest workers had experienced for years - WHD frequently responded inadequately to complaints, leaving workers vulnerable. ${ }^{73}$ This study found: (1) WHD was slow to respond to complaints; (2) cases were "resolved" based on unverified information provided by the employer; and (3) WHD was reluctant to compel employers to pay when violations had been found. ${ }^{74}$

When WHD has found substantial violations, ETA has subsequently failed to remove employers from the H-2 program. ETA has rarely employed its procedures for decertifying or barring

68. Hill, supra note 43, at 153 (describing how most guest workers do not know where such offices are located, and even if guest workers do, that such offices operate only during business hours and often have workers who speak only English).

69. S. POVERTY LAW CTR., supra note 14, at 29; Hall, supra note 12, at 531.

70. See, e.g., Elmore, supra note 27, at 553; Hill, supra note 43, at 152-53.

71. S. POVERTY LAW CTR., supra note 14, at 29. There is no data on the number of H-2A employers that year. In 2007, however, there were an estimated 6,700 employers certified to employ H-2A workers. Id.

72. See Hill, supra note 43 , at 153 (noting that even when WHD does successfully carry out an investigation, "the fines and other remedies are generally so little they are ineffective as a means of deterring future violations.").

73. U.S. GOV'T ACCOUNTABILITY OfFICE, GAO-09-458T, WAGE AND HOUR Division's COMPLAINT InTAKE AND InVESTIGATIVE PROCESSES LEAVE LOW WAge Workers VULNERABLE TO WAGE THEFT 1 (2009), available at http://www.gao.gov/assets/130 /122107.pdf.

74. Id. An earlier study found that over time, WHD had reduced the number of investigations by 36 percent between 1975 and 2004. ANNETTE BERNHARDT \& SIOBHÁN MCGRATH, BRENNAN CTR. FOR JustiCE, TRENDS IN WAGE AND HOUR ENFORCEMENT BY THE U.S. DEPARTMENT OF LABOR, 1975-2004 (2005), available at http://www.brennancenter.org /page/-/d/download_file_35553.pdf. 
employers from either H-2 program. ${ }^{75}$ In 2009 , for example, thirteen employers were barred nationally out of the estimated 13,800 employers that participate in the $\mathrm{H}-2$ program. ${ }^{76}$ The regulatory framework arguably requires the government to meet a high standard of proof in order to decertify employers. ${ }^{77}$ ETA, for example, failed to bar an H-2A employer who had allegedly been involved in the physical abuse and starvation of its workers. ${ }^{78}$ Despite the welldocumented abuses within these programs, ETA has thus far failed to perform its gatekeeping function to exclude the participation of employers that engage in fraud or abuse.

Even when labor abuses against guest workers rise to a criminal level, criminal charges are infrequently brought against the employer. Local law enforcement, particularly in the rural communities where many of the guest workers reside, has generally not been hospitable to guest workers. In one instance, a local sheriff pursued a criminal investigation of a legal-services attorney simply because she represented H-2A workers who had quit their jobs because of abusive conditions. ${ }^{79}$ Legal-services organizations and

75. 29 C.F.R. $\S 501.20$ (2011); 20 C.F.R. $§ 655.72-.73$ (2011); Hill, supra note 43, at $152-53$.

76. Hill, supra note 43, at 153 ("By way of example, the U.S. DOL website reports that eight out of approximately 6,500 H-2A employers in 2009 have been temporarily barred from employing H-2A workers, and that five out of approximately 7,300 employers in 2009 have been temporarily barred from employing H-2B workers."); see also David North, Taking Names: List of Firms Barred from Foreign Worker Programs Likely Just Scratches the Surface, CTR. FOR IMMigR. STUD. (Apr. 2011), http://cis.org/Debarred-Firms-2011 ("Similarly, in FY 2009 there were 7,665 approved applications for H-2A farmworkers, and the Department of Labor's list of debarred participants consists of six names. Again, that is a multi-year list. That ratio is 1 to 1,278. The H-2B program has about as many approved applications as the H-2A program, and perhaps a roughly comparable number of employers. There were 5,998 certified applications in FY 2009. The GAO report and ICE press releases have identified 12 violators. That ratio is 1 to 500.”).

77. 20 C.F.R. $\S \S 501.20,655.73$ (2011).

78. Lee, supra note 45; Stuart Steers, Meaner Pastures, Westword, Feb. 1, 2001, at 25.

79. Letter from Kimi Jackson, Attorney, Colo. Legal Servs., to Anne B. Filbert, Attorney, Filbert \& Assocs., P.C. (Mar. 21, 2006) (on file with author); Moffat Cnty. Sheriff's Office, Incident Report, Case Report No. 05S00839 (Oct. 31, 2005) (on file with author); Moffat Cnty. Sheriff's Office, Offense Report 05S00839 (Nov. 9, 2006) (on file with author); Moffat Cnty. Sheriff's Office, Offense Report 06S00380 (May 30, 2006) (on file with author); Moffat Cnty. Sheriff's Office, Supplemental Offense Report 05S00839.1 (Nov. 9, 2006) (on file with author); Moffat Cnty. Sheriff's Office, Supplemental Offense Report 05S00839.2 (Nov. 9, 2006) (on file with author); Moffat Cnty. Sheriff's Office, Supplemental Offense Report 06S00380.1 (June 9, 2006) (on file with author); Moffat Cnty. Sheriff's Office, Supplemental Report, Case Report No. 05S00839.2 (Jan. 30, 2006) (on file with author); Letter from Leslie L. Schluter, Attorney, 
union organizers have also been charged or threatened with trespass by local law enforcement when visiting $\mathrm{H}-2 \mathrm{~A}$ workers. ${ }^{80}$ While local law enforcement's level of cooperation may vary depending on the jurisdiction, guest workers have not historically had success with local law enforcement addressing abusive conduct by an employer. ${ }^{81}$

Despite the advent of federal human-trafficking legislation that created new tools for prosecuting debt bondage, forced labor, and the unlawful confiscation of documents, there have been relatively few federal prosecutions for human-trafficking crimes in the guest worker realm. ${ }^{82}$ Commentators have noted that the prosecutions that have occurred often target immigrant employers because criminal acts are a "special evil" reserved for criminal aliens. ${ }^{83}$ In the guest worker context, several prosecutions that have received notoriety have involved mostly immigrant defendants. ${ }^{84}$ One recent case involved the prosecution of Global Horizons, which brought over hundreds of Thai H-2A workers and subjected them to debt bondage and forced labor. ${ }^{85}$ The prosecution centered on the owner of the

Brooks \& Schluter LLP, to Deputy Cortland Folks, Moffat Cnty. Sheriff's Office (Mar. 23, 2006) (on file with author).

80. LANCE COMPa, Human RightS Watch, UnFAir AdVANTAGE: Workers' FreEdom OF ASSOCIATION IN THE UNited STATES UNDER INTERNATIONAL HuMAN RightS STANDARDS 154-55 (Cynthia Brown ed., 2004).

81. One notable exception is the New York State Attorney General, who has taken on carnival operators with H-2B workers. See, e.g., Press Release, N.Y. State Office of the Attorney Gen., Attorney General Cuomo Secures Hundreds of Thousands in Restitution for Carnival Workers Discriminated Against and Cheated Out of Proper Pay (Aug. 31, 2009), http://www.ag.ny.gov/press-release/attorney-general-cuomo-secures-hundreds-thousandsrestitution-carnival-workers.

82. The Equal Employment Opportunity Commission (EEOC), which has no criminal jurisdiction, has taken on a few high profile cases of human trafficking in the guest worker realm. See Part II.C for further discussion.

83. Chacón, supra note 27, at 3035-36; see also Jayashri Srikantiah, Perfect Victims and Real Survivors: The Iconic Victim in Domestic Human Trafficking Law, 87 B.U.L. REV. 157, 203 (2007) (stating that the focus on foreign female victims overlooks the fact that in addition to the aliens who are trafficking, U.S. citizens and corporations exploit the trafficked workers).

84. See Mark Niesse, Aloun Farms: Charges Dropped Against Sou Brothers in Hawaii Human Trafficking Case, HuFFINGTON POST (Aug. 5, 2011, 5:19 AM), http://www.huffington post.com/2011/08/05/aloun-farms-charges-dropped-human-trafficking_n_919261.html; see infra notes 85-87. But see United States v. Farrell, 563 F.3d 364, 373 (8th Cir. 2009); United States v. Bradley, 390 F.3d 145 (1st Cir. 2004).

85. Indictment at 3-4, United States v. Orian, No. CR 10-00576, 2010 WL 3440258 (D. Haw. Sept. 1, 2010). The charges have since been dismissed by the federal government on the basis that the government did not believe that it would be able "to prove the elements of the charged offenses beyond a reasonable doubt." Jennifer Sinco Kelleher, Feds Dismiss Largest U.S. 
company, Mordechai Orian, an Israeli immigrant, along with his employees and several Thai recruiters. ${ }^{86}$ Another case involved an Uzbek organized-crime ring that exploited H-2B workers in hotels and other service jobs in fourteen states. ${ }^{87}$ Meanwhile, mainstream corporations that could have been prosecuted for having committed crimes against workers are simply held liable for more technical violations involving immigration paperwork. ${ }^{88}$

The government's failure to enforce the rule of law with respect to guest workers contributes to the overall failure of these programs to stem the tide of abuses. This failure stems not only from the lack of resources and will but also from the structural inadequacies of the regulatory framework. While the government, however, has recently committed to increase enforcement of the H-2A program by launching a new initiative to tackle labor abuses against farm workers, ${ }^{89}$ at its core, the government still refuses to redesign its policies in a meaningful way that would address this exploitation. ${ }^{90}$ This continued contradiction in policies reflects a failure to resolve the economic reality of needing such workers with a commitment to giving them full rights. ${ }^{91}$ As long as the government maintains this ambivalence, guest workers will continue to participate in a system that sanctions, if not promotes, abuse and exploitation.

Human Trafficking Case, HuFFINGTON POST (July 20, 2012), http://www.huffingtonpost.com /huff-wires/20120720/us-human-trafficking-farm-workers/.

86. Indictment at 1-3, United States v. Orian, No. CR 10-00576, 2010 WL 3440258 (D. Haw. Sept. 1, 2010); see also Bowe, supra note 51, at 63-64 (illustrating the structure of the company).

87. Press Release, Office of the U.S. Attorney for the W. Dist. of Mo., Eight Uzbekistan Nationals Among 12 Charged with Racketeering, Human Trafficking, Immigration Violations: \$6 Million Scheme to Employ Illegal Aliens at Hotels, Other Sites in 14 States (May 27, 2009), http://www.justice.gov/usao/mow/news2009/giantlabor.ind.htm.

88. Chacón, supra note 27, at 3032-34.

89. Press Release, U.S. Dep't of Labor, Statement by U.S. Secretary of Labor on U.S. Farmworkers and Their Families (Sept. 16, 2010), http://www.dol.gov/opa/media/press/opa /OPA20100850.htm.

90. See supra notes $43-46$ and accompanying text. H-2A workers are exempt from the major federal legislation, the Migrant and Seasonal Agricultural Worker Protection Act, which provides farm workers with redress for false recruitment, housing, pay, and working conditions. 29 U.S.C. $\S 1802(8)$ (B)(ii) (2006). H-2B workers are exempt from the requirements such as employer paid housing and access to federally funded legal services. Rathod, supra note 39, at 27; Read, supra note 39 , at 433 .

91. See Ontiveros, supra note 43 , at 938 . 


\section{PRivate Civil Remedies}

In order to address a number of the systemic abuses within the guest worker programs, this Article examines the viability of using private civil remedies contained within the Trafficking Victims Protection Act, the Racketeer Influenced and Corrupt Organization Act, and antidiscrimination laws. These laws use a "private attorney general" enforcement model by providing for a private right of action to reach criminal conduct. ${ }^{92}$ An examination of these private civil remedies suggests that they can be used to reach the more egregious forms of employer misconduct that naturally arise from a system that gives employers total control over their workers. The use of such remedies by guest workers can also contribute to reshaping the law by broadening the reach of such private civil remedies to address different forms of exploitation.

\section{A. Trafficking Victims Protection Act}

Congress enacted the TVPA to combat human trafficking through prosecution, prevention, and protection of victims. ${ }^{93}$ Under the TVPA, the government expanded prosecutorial tools to pursue traffickers. ${ }^{94}$ Victims of human trafficking are also eligible for protections, such as social services and immigration relief. ${ }^{95}$ Further, the TVPA created a private right of action for victims of human trafficking. ${ }^{96}$

Much of the criticism pertaining to the TVPA is devoted to the narrowness with which the government has implemented the mandate of the statute, particularly in viewing who is considered a "worthy" victim for purposes of prosecution or issuance of benefits. ${ }^{97}$ In contrast, the private right of action under the TVPA has

92. They also provide a way for guest workers to assert claims in federal court. Guest workers can append their related state-law claims to their federal case pursuant to 28 U.S.C. $\S 1367$, especially those that arise from run-of-the-mill contract violations under the regulations. See 28 U.S.C. $\S 1367$ (detailing the requirements for the exercise of supplemental jurisdiction).

State courts in rural jurisdictions, where workers are usually located, can show bias against workers. Holley, supra note 27, at 608-13.

93. See supra note 21.

94. 18 U.S.C. $\S \S 1589-94,1596(2006)$.

95. 22 U.S.C. $\S 7105(b)(1)(A),(c)(3) ; 8$ U.S.C. $\S 1101(a)(15)(T)$.

96. 18 U.S.C. $\S 1595$.

97. See, e.g., Chacón, supra note 27, at 3022-23; Chacón, supra note 16, at 1615; Chang \& Kim, supra note 27, at 325; Joyce Koo Dalrymple, Human Trafficking: Protecting Human Rights 
been viewed as one of its fairly positive features. ${ }^{98}$ Of all the remedies created by the TVPA, only the private right of action does not depend on government action or approval for its use. Many of the cases utilizing the private right of action, in fact, have proceeded without any parallel criminal prosecution. ${ }^{99}$

Because many of the abuses inherent in the guest worker programs, such as recruitment debts, threats of deportation, and the confiscation of documents, are characteristic of human trafficking crimes, the private right of action under the TVPA is especially well suited to address these abuses. The private right of action, codified at 18 U.S.C. $\S 1595$, provides a civil remedy for any violation of the criminal laws addressing peonage, slavery, and human trafficking. ${ }^{100}$ To date, all reported cases utilizing the private right of action involve cases of labor exploitation. ${ }^{101}$ These cases have broadened the scope

in the Trafficking Victims Protection Act, 25 B.C. THIRD WORLD L.J. 451, 473 (2005); Dina Francesca Haynes, (Not) Found Chained to a Bed in a Brothel: Conceptual, Legal and Procedural Failures to Fulfill the Promise for the Trafficking Victims Protection Act, 21 GEO. ImMigR. L.J. 337, 350 (2007); Kevin Shawn Hsu, Note, Masters and Servants in America: The Ineffectiveness of Current United States Anti-Trafficking Policy in Protecting Victims of Trafficking for the Purposes of Domestic Servitude, 14 GEO. J. ON POVERTY L. \& POL'Y 489, 497 (2007); Loftus, supra note 55, at 185; Ankita Patel, Back to the Drawing Board: Rethinking Protections Available to Victims of Trafficking, 9 SEATTLE J. FOR SOC. JUST. 813, 828 (2011); April Rieger, Missing the Mark: Why the Trafficking Victims Protection Act Fails to Protect Sex Trafficking Victims in the United States, 30 HARV. J.L. \& GENDER 231, 246 (2007); Hussein Sadruddin et al., Human Trafficking in the United States: Expanding Victim Protection Beyond Prosecution Witnesses, 16 STAN. L. \& POL'Y REV. 379, 395 (2005); Srikantiah, supra note 83, at 195; Robert Uy, Blinded by Red Lights: Why Trafficking Discourse Should Shift Away from Sex and the "Perfect Victim" Paradigm, 26 BERKELEY J. GENDER L. \& JUST. 204, 207-08 (2011).

98. Kim, supra note 31, at 250; Kathleen Kim \& Kusia Hreshchyshyn, Human Trafficking Private Right of Action, 16 HASTINGS WoMEN's L.J. 1, 1 (2004); Shannon Lack, Note, Civil Rights for Trafficked Persons: Recommendations for a More Effective Civil Remedy, 26 J.L. \& CoM. 151, 152 (2008); Jennifer S. Nam, Note, The Case of the Missing Case: Examining the Civil Right of Action for Human Trafficking Victims, 107 COLUM. L. REV. 1655, 1655 (2007).

99. Kim, supra note 31, at 293 (stating that out of thirty-one cases brought under the private right of action under the TVPA, twenty-three have proceeded in absence of a parallel criminal action).

100. 18 U.S.C. $\S \S 1581-92$. This includes the human trafficking crimes of forced labor, trafficking, and unlawful conduct with respect to documents. 18 U.S.C. $\S \S 1589-90,1592$.

101. At the time of writing, none of the reported cases utilizing the private right of action under the TVPA involved claims of sex trafficking. See Theodore R. Sangalis, Comment, Elusive Empowerment: Compensating the Sex Trafficked Person Under the Trafficking Victims Protection Act, 80 FORDHAM L. REV. 403, 427 (2011). This is in marked contrast to the federal prosecutions under the TVPA, which have favored victims of sex trafficking or victims of labor trafficking who were subject to sexual violence. Chang \& Kim, supra note 27, at 324-25; Srikantiah, supra note 83 , at 185 . Overall, the number of labor prosecutions has increased over recent years. Shelley Cavalieri, The Eyes that Blind Us: The Overlooked Phenomenon of 
of labor exploitation that is considered to be human trafficking. ${ }^{102}$ The 2008 amendments to the TVPA further reinforce this broader reading as well as expand the scope of liability under the TVPA. ${ }^{103}$

Amendments to the TVPA in 2008 reinforce that physical force is unnecessary for the crime of forced labor. ${ }^{104}$ They codify a broader concept of coercion that was discussed in both the original legislative history and several early judicial decisions. ${ }^{105}$ An employer might coerce a worker by causing him to believe that if he did not labor he would suffer "serious harm," meaning "any harm, whether physical or nonphysical, including psychological, financial, or reputational harm, that is sufficiently serious." 106 Further, the amendments include a consideration of the victim's particular situation in determining whether the harm is sufficiently serious "to compel a reasonable person of the same background and in the same circumstances to perform or to continue performing labor or services in order to avoid incurring that harm." 107 The amendments also clarify that threatened abuse of the law is coercive if it was used "for any purpose for which the law was not designed, in order to exert pressure on another person." 108

Guest workers can take advantage of this expanded concept of nonphysical coercion under the TVPA since most guest worker cases do not involve physical abuse of the workers but rather threats of

Trafficking into the Agricultural Sector, 31 N. ILL. U. L. REV. 501, 506-10 (2011). However, they still remain low compared to the number of victims of human trafficking certified by the U.S. Department of Homeland Security. Id.

102. Kathleen Kim, The Coercion of Trafficked Workers, 96 IowA L. REV. 409, 457 (2011). Kathleen Kim discusses TVPA case law and the development of what she calls "situational coercion," which "evaluates all the circumstances surrounding the alleged trafficking scenario, paying special attention to power inequalities and the workers' individual characteristics that may render them vulnerable to exploitation." Id. She aptly notes, however, that the TVPA does inevitably draw a line pronouncing that only some exploitation is ultimately coerced, while arguably, all exploitation is coercive. Id.

103. William Wilberforce Trafficking Victims Reauthorization Act of 2008, Pub. L. No. 110147, 122 Stat. 5044 (2008).

104. 18 U.S.C. $\S 1589$ (c).

105. H.R. REP. NO. 106-939, at 101 (2000) (Conf. Rep.); United States v. Bradley, 390 F.3d 145, 150-51 (1st Cir. 2004); United States v. Garcia, No. 02-CR-110S-01, 2003 U.S. Dist. LEXIS 22088, at *21-22 (W.D.N.Y. Dec. 2, 2003).

106. 18 U.S.C. $\S 1589(\mathrm{c})(2)$.

107. Id.

108. 18 U.S.C. $\S 1589(c)(1)$. 
deportation as the main coercive element. ${ }^{109}$ Under the TVPA, obtaining labor through threats of deportation can amount to an "abuse of law or legal process." 110 Guest workers may face a hurdle because threats of deportation can also appear to be advisements of legitimate consequences for noncompliance with the terms of an $\mathrm{H}-2$ job. ${ }^{111}$ Under 18 U.S.C. $\S 1589(c)(1)$, however, guest workers can argue that the threat of deportation is being used for a "purpose for which the law was not designed" when the objective is to intimidate and coerce them. ${ }^{112}$ In Ramos-Madrigal v. Mendiola Forestry Service, $L L C,{ }^{113} \mathrm{H}-2 \mathrm{~B}$ forestry workers were threatened with serious immigration consequences and reports to immigration if they were to leave the work prior to the end of their contract. ${ }^{114}$ By examining the context of the threat, which included retaining personal documents, the court rejected defendants' argument that threats to report H-2B workers to immigration if they left their employment were merely informational rather than a "threatened abuse of the legal process" to

109. See, e.g., Complaint for Damages and Declaratory Relief, Ruiz v. Fernandez, No. 11-cv3088-RMP (E.D. Wash. Sept. 2, 2011); Complaint, Samaniego Fernandez v. John Peroulis \& Sons Sheep, Inc., No. 11-cv-01132-MSK-MJW (D. Colo. Apr. 28, 2011); Amended Complaint, Razura Jiminez v. Vanderbilt Landscaping LLC, No. 11-cv-00276 (M.D. Tenn. Apr. 6, 2011); Plaintiff's Original Complaint, Ramos-Madrigal v. Mendiola Forestry Servs., LLC, No. 10-cv01078-RTD (W.D. Ark. Dec. 10, 2010); Plaintiff's Original Complaint, Antonio-Morales v. Bimbo's Best Produce, Inc., No. 08-cv-5150-AJM-JCW, 2009 WL 4060936 (E.D. La. Jan. 26, 2009); Complaint-Class Action and Collective Action, David v. Signal Int'l LLC, No. 08-1220, 2008 WL 1751667 (E.D. La. Mar. 7, 2008); Amended Complaint, Asanok v. Million Express Manpower, Inc., No. 5:07-cv-00048-BO (E.D.N.C. Aug. 24, 2007); Complaint, Aguilar v. Imperial Nurseries, No. 07CV00193, 2007 WL 1183549 (D. Conn. Feb. 28, 2007).

110. 18 U.S.C. § 1589(a)(3); accord United States v. Calimlim, 538 F.3d 706, 713 (7th Cir. 2008); Nuñag-Tanedo v. E. Baton Rouge Parish Sch. Bd., 790 F. Supp. 2d 1134, 1146 (C.D. Cal. 2011); Garcia, 2003 U.S. Dist. LEXIS 22088, at *22-23.

111. See, e.g., United States v. Bradley, 390 F.3d 145, 151 (1st Cir. 2004). In the H-2A context, for example, employers mistakenly believe that they have the prerogative to effect a guest worker's removal from the United States. H-2 workers, like any other workers, are free to walk off the job. H-2A workers, for example, have a period of thirty days to either depart the United States or seek an extension based on a subsequent offer of employment. 8 C.F.R. $\S 214.2$ (h)(5)(viii)(B) (2012)

112. 18 U.S.C. $§ 1589$ (c)(1); see Ramos v. Hoyle, No. 08-21809, 2008 U.S. Dist. LEXIS 102677, at*11 (S.D. Fla. Dec. 19, 2008); see also Calimlim, 538 F.3d at 713 (examining whether the threat was "directed to an end different from those envisioned by the law"). The Supreme Court has used such contextual analysis to determine whether reporting an undocumented worker was for retaliatory, rather than legitimate purposes. Sure-Tan, Inc. v. Nat'l Labor Relations Bd., 467 U.S. 883, 895 n.6 (1984) (finding evidence that the reporting of undocumented workers constitutes retaliation for the workers' protected activity under the NLRA).

113. 799 F. Supp. 2d 958 (W.D. Ark. 2011).

114. Id. at 960 . 
ensure that the workers did not leave their employment. ${ }^{115}$ Because of the common use of threats of deportation to control guest workers, ${ }^{116}$ an examination of the threats' contextual circumstances is particularly significant to establishing nonphysical coercion. ${ }^{117}$

Further, the TVPA's consideration of the victim's particular situation should be used to give the necessary explanation of how coercion operates within the guest worker context. While guest workers are not normally subject to physical restraint, other individual circumstances may explain why they are not free to leave their employment. In Ramos-Madrigal, the court rejected defendants' argument that the H-2B workers were free to return to Mexico at any time because it recognized that holding $\mathrm{H}-2 \mathrm{~B}$ extension documents, in the course of threatening serious immigration consequences, was sufficient to "prevent [the workers] from leaving employment." ${ }^{118}$ The confiscation of guest worker passports and visas is not an uncommon practice by employers. ${ }^{119}$ In other cases, courts have confirmed that physical opportunities to escape cannot be equated with a lack of coercion under the TVPA if the circumstances indicate that the worker is otherwise compelled to remain. ${ }^{120}$ Because a guest worker's return to his home country may facially appear to be an exit option, guest workers need to present

115. Id.; see also Velasquez Catalan v. Vermillion Ranch Ltd. P'ship, No. 06-cv-01043, 2007 U.S. Dist. LEXIS 567, at *24 (D. Colo. Jan. 4, 2007) (finding that defendants' threat to have H-2A workers deported was sufficient to support a claim under 18 U.S.C. § 1589(a)(3)).

116. S. POVERTY LAW CTR., supra note 14, at 16.

117. See United States v. Farrell, 563 F.3d 364, 373 (8th Cir. 2009) (finding the employers' threats of deportation against H-2B workers to be illegal coercion under 18 U.S.C. $\S 1584$ despite the fact they were made as a consequence of failing to abide by the employers' rules). The court in Farrell also took into account the "special vulnerabilities" of the workers, which included that they were on temporary work visas sponsored by the employers and were entirely dependent on them for their housing and transportation. Id. at 374.

118. Ramos-Madrigal, 799 F. Supp. 2d at 960.

119. Colo. Legal Servs., supra note 53, at 15; S. POVERTY LAW CTR., supra note 14, at 15-16; see also Temporary Agricultural Employment of H-2A Aliens in the United States, 75 Fed. Reg. 6884, 6923 (Feb. 12, 2010) (codified at 20 C.F.R. pt. 655) (DOL recognizing "the worker's right not to relinquish possession of his or her passport to the employer").

120. See, e.g., Shukla v. Sharma, No. 07-CV-2972(CBA), 2009 U.S. Dist. LEXIS 90044, at *41-42 (E.D.N.Y. Aug. 21, 2009); Ramos v. Hoyle, No. 08-21809, 2008 U.S. Dist. LEXIS 102677, at*13 (S.D. Fla. Dec. 19, 2008). 
evidence that such a return is not a true option because it would result in psychological, financial, or reputational harm. ${ }^{121}$

Guest workers should not be deterred from establishing TVPA claims even though they may have characteristics that are inconsistent with the iconic passive victim of human trafficking. ${ }^{122}$ Guest workers willingly seek out visas to work temporarily in the United States and have a strong interest in not returning home early. ${ }^{123}$ In a case involving professional guest workers, NuñagTanedo v. East Baton Rouge Parish School Board, ${ }^{124}$ the court noted that plaintiffs, who were able to establish a claim for forced labor, "not only wanted, but needed to continue working," because of the massive debts they had accumulated in order to obtain their jobs. ${ }^{125}$ A guest worker's strong desire to continue working and avoid being fired should similarly not undermine a claim alleging that the work was obtained through coercion. ${ }^{126}$ The conflation of the desire and necessity to work as a guest worker may be tied to any number of reasons, such as recruitment debts or the personal humiliation in failing to provide for one's family. ${ }^{127}$

Mainstream employers of guest workers often use contractors, supervisors, or recruiters to interact with employees, and it may be these individuals who commit the egregious abuses against workers. ${ }^{128}$ The TVPA can reach an employer who knowingly benefits financially because of "participation in a venture" that the employer should have known was engaged in human trafficking. ${ }^{129}$

121. 18 U.S.C. $§ 1589(c)(2)$ (2006). See, e.g., Complaint at 8, Espejo Camayo v. John Peroulis \& Sons Sheep, Inc., No. 10-cv-00772-MSK-MJW, 2012 U.S. Dist. LEXIS 65494 (D. Colo. May 10, 2012) (pleading that being returned home to Peru would create financial and reputational harm).

122. Srikantiah, supra note 83 , at 197-98 (describing that the TVPA favors "a victim completely under the trafficker's control and lacking in free will, unable even to escape until she is rescued by law enforcement").

123. Despite being cheated, many guest workers see their employment as the best chance to better the lives of their families. FARMWORKER JUSTICE, supra note 14, at 17; S. POVERTY LAW CTR., supra note 14, at 12.

124. 790 F. Supp. 2 d 1134 (C.D. Cal. 2011).

125. Id. at 1146 .

126. See United States v. Farrell, 563 F.3d 364, 375 (8th Cir. 2009) (finding that H-2B workers established that their employment was involuntary, for at least some portion of their stay, even though they had left the country and returned to their employment).

127. S. POVERTY LAW CTR., supra note 14, at 9-14; Bowe, supra note 51, at 65.

128. S. POVERTY LAW CTR., supra note 14 , at 32-33.

129. 18 U.S.C. $\S \S 1589$ (b), 1595(a) (2006). 
While an employer still, at a minimum, needs to have reckless disregard of the human trafficking acts for liability to attach, a mainstream employer cannot as easily distance itself from contractors or recruiters who have actively committed human trafficking acts against their employees. ${ }^{130}$

The use of the private right of action under the TVPA by various immigrant workers, including guest workers, has contributed to the positive reshaping of the TVPA. By effectively leveraging the TVPA, guest workers can target mainstream employers, as the case law reveals the broad reach of the TVPA and the broad class of individuals it protects. ${ }^{131}$ In particular, guest workers can leverage recent court decisions that emphasize the contextual circumstances of the employment relationship, which have ultimately broadened the kind of coercion that is actionable under the TVPA. ${ }^{132}$ Through its private right of action, therefore, the TVPA gives guest workers a tool to request redress for the criminal acts of their employers.

\section{B. Racketeer and Influenced Corrupt Organization Act}

Guest workers can also harness civil RICO to hold employers accountable even when the government fails to do so. ${ }^{133}$ RICO was enacted in 1970 to combat organized crime by imposing both criminal and civil liability to attack the sources of its revenue. ${ }^{134}$ The private right of action under civil RICO can reach criminal activity associated with fraudulent recruitment practices, deportation threats,

130. Despite its broader reach, the new reckless-disregard standard will undoubtedly still result in shielding employers from liability through the practice of contracting and subcontracting. Chacón, supra note 27, at 3003.

131. Nuñag-Tanedo v. E. Baton Rouge Parish Sch. Bd., 790 F. Supp. 2d 1134, 1147 (C.D. Cal. 2011) (stating that "it is the duty of this Court to provide a forum for the alleged victims of forced labor, regardless of the severity of the alleged circumstances").

132. Kim, supra note 102 , at $458-59$.

133. The labor movement has disfavored civil RICO because employers have used it against unions by employers to undermine union campaigns. See, e.g., James J. Brudney, Collateral Conflict: Employer Claims of RICO Extortion Against Union Comprehensive Campaigns, $83 \mathrm{~S}$. CAL. L. REV. 731, 733-35 (2010); Paul More, Protections Against Retaliatory Employer Lawsuits After BE\&K Construction v. NLRB, 25 BERKELEY J. EMP. \& LAB. L. 205, 215 (2004); Howard S. Simonoff \& Theodore M. Lieverman, The Rico-ization of Federal Labor Law: An Argument for Broad Preemption, 8 LAB. LAW. 335, 336-37 (1992). Notwithstanding these critiques, this Part argues that civil RICO can be used to the benefit of immigrant workers.

134. See generally GREGORY P. JOSEPH, CIVIL RICO: A DEFINITIVE GUIDE 1-3 (2d ed. 2000) (stating the purposes behind the creation of RICO). 
human trafficking, and fraud related to the $\mathrm{H}-2 \mathrm{~A}$ and $\mathrm{H}-2 \mathrm{~B}$ visa paperwork. ${ }^{135}$

There has been scant attention paid to the use of civil RICO claims by immigrant workers against employers for abusive labor practices. ${ }^{136}$ In contrast, the use of civil RICO against employers that violate immigration laws by hiring undocumented workers is well known. ${ }^{137}$ Such lawsuits gained notoriety as an end-run around government enforcement of the unlawful hiring of undocumented workers. ${ }^{138}$ Civil RICO, however, can also operate as an express antidote to lax government enforcement of labor abuses to the benefit of guest workers. ${ }^{139}$

Under 18 U.S.C. $§ 1964(c)$, a civil RICO violation can be established by showing that there has been an injury caused by a pattern of racketeering activity. ${ }^{140}$ Racketeering activity includes a

135. See infra notes $142-153$ and accompanying text.

136. Eleanor G. Carr, Note, Search for a Round Peg: Seeking a Remedy for Recruitment Abuses in the U.S. Guest Worker Program, 43 ColuM. J.L. \& Soc. ProBS. 399, 417-24 (2010) (noting the potential barriers for guest workers to recover foreign recruitment fees with a civil RICO claim); Joey Hipolito, Learning from RICO: Immigration Enforcement Through Employer Accountability, 20 BERKELEY LA RAZA L.J. 67, 82 (2010) (discussing the failure of the civil RICO claims in the Zavala v. Wal-Mart Stores, Inc. case brought by immigrant workers).

137. Williams v. Mohawk Indus., 465 F.3d 1277, 1292 (11th Cir. 2006) (allowing employees to proceed with a civil RICO claim based on their employer's illegal hiring of undocumented workers that resulted in a reduction of hourly wages); Mendoza v. Zirkle Fruit Co., 301 F.3d 1163, 1169-72 (9th Cir. 2002) (finding that employees had standing to sue their employer over the hiring of undocumented workers that caused wages to be depressed); Commercial Cleaning Servs., L.L.C. v. Colin Serv. Sys., Inc., 271 F.3d 374, 378-79 (2d Cir. 2001) (allowing a competitor to proceed with a civil RICO claim based on the unlawful business profits gained by hiring undocumented workers). But see Canyon Cnty. v. Syngenta Seeds, Inc., 519 F.3d 969, 980 (9th Cir. 2008) (determining that the county did not have standing to sue companies under civil RICO that hired undocumented workers); Baker v. IBP, Inc., 357 F.3d 685, 690-92 (7th Cir. 2004) (dismissing civil RICO claims brought by employees alleging that the hiring of undocumented workers resulted in depressed wages).

138. Nancy Cleeland, New Angle in Fight Against Hiring Illegal Immigrants, L.A. TIMES (Apr. 3, 2002), http://articles.latimes.com/2002/apr/03/business/fi-ricomo3; Brian Grow, A Body Blow to Illegal Labor?, Bus. WK. (Mar. 27, 2006), http://www.businessweek.com/stories/2006 -03-26/a-body-blow-to-illegal-labor.

139. See, e.g., Nuñag-Tanedo v. E. Baton Rouge Parish Sch. Bd., 790 F. Supp. 2d 1134, 1148 (C.D. Cal. 2011) (holding that Filipino immigrant workers "sufficiently stated a claim for RICO violations").

140. 18 U.S.C. $\S 1964$ (c) (2006). Further, the injury needs to be economic and proximately caused by the predicate acts. Berg v. First State Ins. Co., 915 F.2d 460, 464 (9th Cir. 1990); Grogan v. Platt, 835 F.2d 844, 846-48 (11th Cir. 1988). A plaintiff needs to allege not only that her injuries were direct, rather than derivative, but also that they were proximately caused by the RICO violation. Holmes v. Sec. Investor Prot. Corp., 503 U.S. 258, 268-70 (1992). Some factors to examine as to whether the injury is too remote include: 
number of crimes that have been statutorily enumerated at 18 U.S.C. $\S 1961$. A pattern of racketeering activity requires the commission of at least two predicate acts over the course of ten years. ${ }^{141}$ A plaintiff must also establish "standing" by properly asserting a "violation of section 1962," which includes defendant's operation of an “enterprise."142 An “enterprise," as defined by 18 U.S.C. $§$ 1961(4), can be any legal entity as well as a "group of individuals associated in fact although not a legal entity."143 Courts have recognized an "association-in-fact" to include, beyond defendant employers, others who facilitated the exploitation, such as recruiters, immigration attorneys, or U.S. consular officials. ${ }^{144}$

(1) the 'difficult[y]' in 'ascertain[ing] the amount of a[n] [indirect] plaintiff's damages attributable to the violation, as distinct from other, independent factors'; (2) the 'complicated rules' courts would be forced to adopt to 'apportion[] damages among plaintiffs removed at different levels of injury from the violative acts, to obviate the risk of multiple recoveries'; and (3) the existence of a 'directly injured victim[]' who 'can generally be counted on to vindicate the law' and serve the law's 'general interest in deterring injurious conduct.'

Trollinger v. Tyson Foods, Inc., 370 F.3d 602, 613 (6th Cir. 2004) (quoting Holmes, 503 U.S. at 269); see also Oregon Laborers-Emp'rs Health \& Welfare Trust Fund v. Philip Morris Inc., 185 F.3d 957, 963 (9th Cir. 1999) (stating that a "direct relationship between the injury and the alleged wrongdoing" is a key element of proving proximate cause in RICO cases).

141. 18 U.S.C. $§ 1961(5)$ (2006). The pattern must also have "continuity" and "relatedness" meaning that they need to have continued for a sufficiently long period of time and have similar purposes, results, participants, victims, and/or methods of commission. H.J. Inc. v. Nw. Bell Tel. Co., 492 U.S. 229, 239-43 (1989).

142. 18 U.S.C. $\S \S 1964(c), 1962(a)$. The four distinct ways to violate $\S 1962$ are: (1) investment, § 1962(a); (2) acquisition, § 1962(b); (3) participation, § 1962(c); and (4) conspiracy, $\S 1962$ (d). A violation of 18 U.S.C. § 1962(a) requires that a defendant received income derived from a pattern of racketeering activity and used or invested such income in the acquisition, establishment, or operation of any enterprise. A violation of 18 U.S.C. $\S 1962$ (b) requires that a defendant acquire or maintain, through a pattern of racketeering activity, any interest or control of any enterprise. The use of $\S \S 1962$ (a) and 1962(b) is difficult because they require a showing that there was an actual injury from the investment of the income or acquisition of the enterprise. Injury stemming from the commission of predicate acts alone is insufficient. See, e.g., Abraham v. Singh, 480 F.3d 351, 356-57 (5th Cir. 2007) (dismissing claims brought under $\S \S 1962$ (a)-(b) for failure to show the requisite injuries). A violation of 18 U.S.C. $§ 1962$ (c) requires that the defendant, who is employed by or associated with the enterprise, conduct or participate in the conduct of such an "enterprise's affairs through a pattern of racketeering activity." While the actual injury can stem from the racketeering activity, the defendant must be a distinct entity from the enterprise. Cedric Kushner Promotions, Ltd. v. King, 533 U.S. 158, 163 (2001).

143. An "enterprise" includes both legitimate and illegitimate organizations. United States v. Turkette, 452 U.S. 576, 580-81 (1981).

144. David v. Signal Int'l, LLC, 588 F. Supp. 2d 718, 725-26 (E.D. La. 2008); Velasquez Catalan v. Vermillion Ranch Ltd. P'ship, No. 06-cv-01043-WYD-MJW, 2007 U.S. Dist. LEXIS 567 , at *8, *16 (D. Colo. Jan. 4, 2007). 
Several common abuses of guest workers can constitute racketeering acts that are actionable under civil RICO. An employer's exploitation of guest workers is often premised on false promises made to workers at the time of recruitment. ${ }^{145}$ In Magnifico $v$. Villanueva, ${ }^{146}$ the court allowed plaintiffs to proceed on their claims of fraudulent recruitment under a theory that the fraudulent recruitment constituted the predicate acts of mail and wire fraud. ${ }^{147}$ Plaintiffs were citizens of the Philippines who were recruited to work on H-2B visas at various country clubs in Florida and New York. ${ }^{148}$ When they arrived, however, they were placed in severely crowded housing, worked long hours, and faced exorbitant deductions for food, housing, and transportation, despite having been promised that these benefits would be free of charge. ${ }^{149}$ The court accepted that plaintiffs had adequately alleged that defendants committed the racketeering acts of mail and wire fraud by having made false promises or misrepresentations about the terms and conditions of the job and by having used the mail and wires to do so. ${ }^{150}$

Guest workers may argue that employer abuses amount to the commission of the predicate act of visa fraud pursuant to 18 U.S.C. $\S 1546$. Since guest workers are present on $\mathrm{H}-2 \mathrm{~A}$ or $\mathrm{H}-2 \mathrm{~B}$ visas, the employer may have committed fraud associated with their visa applications. The court in Magnifico, for example, held that plaintiffs had sufficiently alleged visa fraud by arguing that the employer's applications for $\mathrm{H}-2 \mathrm{~B}$ visas contained material misrepresentations about the true terms and conditions of the job. ${ }^{151}$ Further, all H-2A

145. Am. Univ. WASh. Coll. OF LAW \& Centro DE los Derechos Del Migrante, InC., supra note 53, at 24; S. POVERTY LAW CTR., supra note 14, at 22-23; see also Hall, supra note 12 , at 531 (discussing how agricultural workers, other than H-2A workers, normally have a federal private right of action under the Migrant and Seasonal Agricultural Worker Protection Act if the employer "does not accurately disclose the terms and conditions of employment at the time of recruitment").

146. 783 F. Supp. 2d 1217 (S.D. Fla. 2011).

147. Id. at 1222,1228 .

148. Id. at $1221-22,1228$.

149. Id. at 1222 .

150. Id. at 1228; see also David v. Signal Int'l, LLC, 588 F. Supp. 2d 718, 721, 726 (E.D. La. 2008) (declining to dismiss civil RICO claims of mail and wire fraud based on false promises made to recruit workers). The use of the mail or wire needs to be for the purposes of executing the fraudulent scheme, but need not be an essential element of the scheme. Schmuck v. United States, 489 U.S. 705, 714-15 (1989).

151. Magnifico, 783 F. Supp. 2d at 1222, 1228; see also Velasquez Catalan v. Vermillion Ranch Ltd. P'ship, No. 06-cv-01043-WYD-MJW, 2007 U.S. Dist. LEXIS 567, at*18-19 (D. 
and $\mathrm{H}-2 \mathrm{~B}$ applications for labor certification require that employers sign under the penalty of perjury that, among other things, the employer will comply with all "Federal, State and local employmentrelated laws and regulations." " 152 Any knowing misrepresentation that the employer would comply with such laws is arguably actionable under the visa-fraud provision. ${ }^{153}$

Employers commonly engage in verbal abuse that can include threats to intimidate and control guest workers. Threats to induce fear, including threats of deportation, can constitute the predicate act of extortion either under 18 U.S.C. $\S 1951$ or via a state-law equivalent of extortion law under 18 U.S.C. $\S 1961(1)(A) .{ }^{154}$ In Nuñag-Tanedo, the court found that plaintiffs, who were professional guest workers, had adequately pleaded the racketeering act of extortion because they had sufficiently alleged that defendants' threats of deportation and financial ruin amounted to the "wrongful use of fear." 155 In particular, the court focused on the circumstances of plaintiffs as immigrant workers who had incurred substantial debts to conclude that the "threatened deprivation of income and the ability to continue working in the United States was wrongful.,"156

Guest workers can also use civil RICO's incorporation of the TVPA, as well as the older antipeonage laws, to reach employers that have committed human trafficking acts, such as forced labor or the

Colo. Jan 4, 2007) (declining to dismiss civil RICO claims based on the predicate act of visa fraud). In order to apply for guest worker visas, employers are required to submit a labor certification application to the DOL, signed under the penalty of perjury, certifying the job description and compliance with all employment-related laws and regulations. See infra note 152.

152. Both H-2A and H-2B employers must submit the ETA 9142 labor certification application. U.S. DEP'T OF LABOR, ETA FORM 9142 apps. A.2, B.1, available at http://www.foreignlaborcert.doleta.gov/form.cfm (follow "Appendix A.2" or "Appendix B.1" hyperlinks) (last visited Dec. 23, 2011).

153. 18 U.S.C. $§ 1546$ (a) (2006) (stating that " $[w]$ hoever knowingly makes under oath, or as permitted under penalty of perjury under section 1746 of title 28, United States Code, knowingly subscribes as true, any false statement with respect to a material fact in any application").

154. Any act of extortion that "obstructs, delays, or affects commerce" violates 18 U.S.C. $\S 1951$. Courts have allowed civil RICO claims based on the racketeering act of extortion to proceed for guest workers who have been threatened with deportation, punitive measures, or imprisonment, albeit with virtually no discussion. See Abraham v. Singh, 480 F.3d 351, 353-54 (5th Cir. 2007); Velasquez Catalan, 2007 U.S. Dist. LEXIS 567, at*21.

155. Nuñag-Tanedo v. E. Baton Rouge Parish Sch. Bd., 790 F. Supp. 2d 1134, 1150-51 (C.D. Cal. 2011). Plaintiffs pleaded the racketeering act of extortion by using the state extortion law, $\S \S 518$ and 519 of the California Penal Code. Nuñag-Tanedo, 790 F. Supp. 2d at 1149.

156. Id. at 1151. 
unlawful confiscation of documents. ${ }^{157}$ A civil RICO claim may be made based on any racketeering act related to human trafficking enumerated at 18 U.S.C. $\S \S 1581-1592 .{ }^{158}$

Plaintiffs can face hurdles in properly pleading a civil RICO claim, and the failure to do so can be the death knell for a case. ${ }^{159}$ Since many civil RICO claims sound in fraud, a complaint must meet the heightened pleading requirements of the "who, what, where and when" required by Federal Rule of Civil Procedure 9(b). ${ }^{160}$ Guest workers, however, can take advantage of case law that permits courts to relax such heightened pleading standards when knowledge of an employer's operations is peculiarly within the possession of defendants. ${ }^{161}$

Guest workers have successfully managed to characterize many egregious abuses in their employment as predicate acts under civil RICO. ${ }^{162}$ Civil RICO's private right of action can extend to abusive acts that are otherwise not actionable under the existing regulatory

157. See, e.g., Abraham, 480 F.3d at 354; Magnifico v. Villanueva, 783 F. Supp. 2d 1217, 1228 n.9 (S.D. Fla. 2011); Velazquez Catalan, 2007 U.S. Dist. LEXIS 567, at *21.

158. 18 U.S.C. § 1961(1)(B).

159. See, e.g., Saucedo v. Five Star Contractors, No. 09-CV-268, 2011 U.S. Dist. LEXIS 60108 , at *8-9 (S.D. Miss. June 6, 2011) (finding civil RICO claims inadequately pleaded but granting leave to attempt to replead); Zavala v. Wal-Mart Stores, Inc., 447 F. Supp. 2d 379, 388 (D.N.J. 2006) (dismissing civil RICO claims after providing leave to replead the claims).

160. Civil RICO claims that do not sound in fraud should not have to be pleaded with particularity. See Velasquez Catalan, 2007 U.S. Dist. LEXIS 567, at *20-21 (suggesting that nonfraud claims do not have to meet 9 (b) requirements). The Supreme Court has declined to extend Federal Rule of Civil Procedure 9(b)'s requirements to nonfraud claims in other contexts. See, e.g., Leatherman v. Tarrant Cnty. Narcotics Intelligence \& Coordination Unit, 507 U.S. 163, 168 (1993) (declining to apply 9(b) to $\S 1983$ claims).

161. See, e.g., Velasquez Catalan, 2007 U.S. Dist. LEXIS 567, at*19-20 (relaxing the 9(b) requirement for identifying which defendants were involved in the fraud relating to visa applications and payroll based on the group published doctrine exception); Vega v. Contract Cleaning Maint., Inc., No. 03-C-9130, 2004 U.S. Dist. LEXIS 20949, at *39-40 (N.D. Ill. Oct. 18, 2004) (relaxing the 9(b) standard for unskilled janitorial and maintenance employees who had no access to information regarding the manner in which each particular defendant participated in the alleged fraud). But see Nuñag-Tanedo v. E. Baton Rouge Parish Sch. Bd., 790 F. Supp. 2d 1134, 1149 (C.D. Cal. 2011) (declining to relax the 9(b) requirements for failure to plead facts related to the mail and wire fraud claim).

162. Notably, some cases have been brought under or in conjunction with state RICO laws. See, e.g., Magnifico, 783 F. Supp. 2d at 1226 n.8; Complaint, Acosta v. Beasley, No. 04 CV 005067 (N.C. Super. Ct. Apr. 13, 2004) (alleging the racketeering act of blacklisting of H-2A workers who had asserted their rights under their contracts). In North Carolina, for example, a criminal law that prohibits the blacklisting of workers can be actionable via the state civil RICO. N.C. GEN. STAT. § 14-355 (2012). Because state RICO laws often incorporate state criminal laws as racketeering acts, they may provide additional avenues to address guest worker exploitation. 
system or regulated by the government. In doing so, guest workers can statutorily seek treble damages to reach the illicit profits made by employers from their exploitation. ${ }^{163}$ Civil RICO claims, therefore, give guest workers another tool for redressing an employer's criminal conduct.

\section{Racial Harassment and \\ Hostile Work Environment}

In the guest worker context, discrimination claims have largely focused on the unlawful preference exhibited toward guest workers over U.S. workers. ${ }^{164}$ The popular media regularly reports on this preference by sympathetically portraying farmers who bemoan the difficulties of being forced to employ U.S. workers who have "gotten soft." ${ }^{\prime 65}$ The subtext of this preference for guest workers is well known. Because of the inherent vulnerability of guest workers, employers are able to "squeeze out maximum productivity at minimal labor cost," while engaging in abusive labor practices. ${ }^{166}$ Not surprisingly, employers may engage in such abuses, in part, because of their underlying prejudices against guest workers. ${ }^{167}$ Being able to prove such discrimination has historically been difficult because of the general lack of evidence that non-guest workers were being treated more favorably. ${ }^{168}$

163. 18 U.S.C. $\S 1964(\mathrm{c})$.

164. In both the H-2A and H-2B program, it is unlawful to discriminate against U.S. workers. 20 C.F.R. $\S \S 655.135(a), 655.20$ (q) (2012). U.S. workers have also brought claims pursuant to Title VII, 8 U.S.C. $\S 1324$ b and 42 U.S.C. $\S 1981$. By contrast, there are very few reported cases where guest workers have alleged violations of antidiscrimination laws. See, e.g., Reyes-Gaona v. N.C. Growers Ass'n, 250 F.3d 861, 866 (4th Cir. 2001) (holding that ADEA claims could not be applied extraterritorially for an $\mathrm{H}-2 \mathrm{~A}$ worker claiming that he had been denied a job in the United States based on his age); Olvera-Morales v. Int'l Labor Mgmt. Corp., 05-CV-00559, 2008 U.S. Dist. LEXIS 3502, at*34-35 (M.D.N.C. Jan. 1, 2008) (permitting sex discrimination claims to proceed against an employer who offered less favorable work to its female H-2B employees).

165. See, e.g., Kirk Johnson, Hiring Locally for Farm Work Is No Cure-All, N.Y. TIMES, Oct. 5, 2011, at A1; Erik Ortiz, Foreign Workers, Not Laid-Off Locals, Filling Seasonal Jobs, PRESS OF ATLANTIC CiTY (Apr. 6, 2010), available at http://www.pressofatlanticcity.com/news /press/cape_may/article_fc82f8a6-40ba-11df-9697-001cc4c002e0.html; Dan Rather, Help Not Wanted?, HufFingtoN POST (Oct. 13, 2010), http://www.huffingtonpost.com/dan-rather/help -not-wanted_b_761132.html.

166. FARMWORKER JUSTICE, supra note 14, at 17.

167. Id. at 27; S. POVERTY LAW CTR., supra note 14, at 34-36.

168. Most employers solely employ guest workers. Leticia Saucedo has noted the inherent difficulties in disparate impact and/or treatment claims for "brown collar" immigrant workers in segregated workplaces because the current proof frameworks hinder successful litigation on these 
A more readily available remedy for guest workers may be to claim racial or national origin harassment based on a hostile work environment. Guest workers can bring racial or national origin discrimination claims for what amounts to criminal behavior by the employer pursuant to Title VII or 42 U.S.C. $§ 1981 .{ }^{169}$ Title VII prohibits employment discrimination based on an individual's race or national origin. ${ }^{170}$ Plaintiffs in Title VII cases may also seek relief under 42 U.S.C. $\S 1981$, which covers discrimination on the basis of race, ethnicity, and sometimes alienage. ${ }^{171}$ Acts of verbal abuse, threats of deportation, or false imprisonment can be used as evidence of animus based on race or national origin. Even if these criminal acts appear facially neutral, guest workers can use these acts to help

claims. Leticia M. Saucedo, The Employer Preference for the Subservient Worker and the Making of the Brown Collar Workplace, 67 OHIO ST. L.J. 961, 982-86 (2006).

169. This discussion is limited to the tools of race and national origin discrimination that are applicable to all guest workers, although the EEOC has taken on an increasing number of cases alleging sex discrimination based on criminal sexual behavior against female immigrant workers. See Complaint, EEOC v. La Pianta, LLC, No. 09-cv-00303-RHW (E.D. Wash. Sept. 30, 2009) (alleging sexual harassment by a supervisor who, among other things, sexually assaulted a female farm worker); Complaint, EEOC v. Willamette Tree Wholesale Inc., No. 09-cv-00690-PK (D. Or. June 18, 2009) (alleging sexual harassment of female farm workers, which included sexual assault); Complaint, EEOC v. Wilcox Farms, Inc., No. 08-cv-01141-MO (D. Or. Sept. 30, 2008) (alleging sexual harassment on behalf of a female farm worker who had suffered from physical sexual assault); EEOC v. Harris Farms, No. 05-16945, 2008 U.S. App. LEXIS 9127, at *4 (9th Cir. Apr. 17, 2008) (affirming a punitive damages award of $\$ 800,000$ against an employer for sex harassment and retaliation by a supervisor).

170. 42 U.S.C. $§ 2000 \mathrm{e}-2(\mathrm{a})(1)$ (2006).

171. Section 1981 provides that "[a]ll persons within the jurisdiction of the United States shall have the same right in every State and Territory to make and enforce contracts ... as is enjoyed by white citizens." Id. § 1981(a). Section 1981 has been extended to include persons of immigrant ethnic groups, so long as the plaintiffs allege that the discrimination is based on their race or ethnicity rather than their national origin. See Fonseca v. Sysco Food Servs. of Ariz., Inc., 374 F.3d 840, 850 (9th Cir. 2004) ("Although national origin discrimination is not within the ambit of $\S 1981$, race has been defined broadly to cover immigrant ethnic groups."). Section 1981 claims are treated similarly to claims brought under Title VII. See, e.g., Eliserio v. United Steelworkers of Am., 398 F.3d 1071, 1076 (8th Cir. 2005); Williams v. Waste Mgmt. of Ill., Inc., 361 F.3d 1021, 1028 (7th Cir. 2004). Section 1981, however, provides for a few advantages over Title VII, including a longer statute of limitations, the lack of caps on certain damages, and the ability to reach smaller employers. Lewis L. Maltby \& David C. Yamada, Beyond "Economic Realities": The Case for Amending Federal Employment Discrimination Laws to Include Independent Contractors, 38 B.C. L. REV. 239, 256-57 (1997). Further, it may also reach alienage discrimination, although the case law is mixed. Compare Bhandari v. First Nat'l Bank of Commerce, 829 F.2d 1343, 1351-52 (5th Cir.) (en banc), vacated, 492 U.S. 901 (1987), opinion reinstated, 887 F.2d 609 (5th Cir. 1989) (per curiam) (holding that the protections of 42 U.S.C. $\S 1981$ do not extend to prohibit alienage discrimination), with Anderson v. Conboy, 156 F.3d 167, 180 (2d Cir. 1998) (holding that 42 U.S.C. $\$ 1981$ provides a claim against private discrimination on the basis of alienage). 
construct a claim of hostile work environment. Further, guest workers can allege a claim of racial or national origin harassment independent of the burden associated with the traditional comparators necessary to establish a disparate treatment or impact claim.

In the case of a hostile work environment based on race or national origin, the legal framework is equivalent to that used for cases of sexual harassment. ${ }^{172}$ An objectionable environment "must be both objectively and subjectively offensive."173 The harassment must be based on race or national origin and be sufficiently severe or pervasive to alter the terms of conditions of employment and create a hostile or abusive environment. ${ }^{174} \mathrm{~A}$ few isolated incidents of racial enmity are insufficient to find liability ${ }^{175}$ because the work environment must be so "heavily polluted with discrimination as to destroy the emotional and psychological stability of the minority [employee]."176

In Chellen v. John Pickle Co., ${ }^{177}$ immigrant workers from India found themselves living and working under substandard conditions. $^{178}$ Multiple derogatory remarks based on the workers' national origin supported the finding of a hostile work environment under Title VII and $\S 1981 .{ }^{179}$ More notably, the court used the employer's threats of physical harm and deportation back to India to support its harassment finding. ${ }^{180}$ In particular, the court examined how the threats to send the workers back to India were coercive because plaintiffs feared the possible harm that awaited themselves

172. Compare 29 C.F.R. $\S 1604.11$ (2012) (EEOC sexual harassment guidelines), with 29 C.F.R. § 1606.8 (2012) (EEOC harassment guidelines on basis of national origin). See also Faragher v. City of Boca Raton, 524 U.S. 775, 787 n.1 (1998) ("Courts of Appeals in sexual harassment cases have properly drawn on standards developed in cases involving racial harassment.").

173. Faragher, 524 U.S. at 787.

174. Harris v. Forklift Sys., Inc., 510 U.S. 17, 21-22 (1993).

175. Snell v. Suffolk Co., 782 F.2d 1094, 1103 (2d Cir. 1986).

176. Hicks v. Gates Rubber Co., 833 F.2d 1406, 1413 (10th Cir. 1987) (quoting Rogers v. EEOC, 454 F.2d 234, 238 (5th Cir. 1971)).

177. 446 F. Supp. 2d 1247 (N.D. Okla. 2006).

178. Id. at $1263-66$.

179. Id. at $1265-66$.

180. Id. 
and their families upon their return, including the potential for financial ruin. ${ }^{181}$

As they did in Chellen, guest workers can present acts of intimidation, including threats of deportation, as harassment based on race and/or national origin. In David v. Signal International, Inc., ${ }^{182}$ $\mathrm{H}-2 \mathrm{~B}$ workers from India alleged that their employer maintained a hostile and abusive work environment based on race, national origin, and alienage through the actions and statements of its personnel in violation of 42 U.S.C. $§ 1981 .{ }^{183}$ Besides offensive language and insults, workers were subjected to multiple threats of deportation and false imprisonment in guarded labor camps. ${ }^{184}$ In EEOC v. Global Horizons, Inc., ${ }^{185}$ H-2A workers from Thailand alleged discriminatory harassment on the basis of race and national origin. ${ }^{186}$ Global Horizons had allegedly engaged in largely criminal behavior by regularly intimidating and threatening workers with deportation, arrest, and physical violence, and by unlawfully confiscating their identification documents. $^{187}$

While neither of these cases has resulted in a court decision on these claims, the viability of a racial or national origin harassment claim based on criminal behavior is promising based on the developments in the analogous claim of sexual harassment. ${ }^{188}$ In sex

\footnotetext{
181. Id.

182. 588 F. Supp. 2d 718, 721 (E.D. La. 2008).

183. Complaint-Class Action and Collective Action, David v. Signal Int'l, LLC, 588 F. Supp. 2d 718 (E.D. La. 2008) (No. 08-1220); see also Complaint, EEOC v. Signal Int'l, LLC, No. 1:11CV179-LG-RHW, 2012 U.S. Dist. LEXIS 7615 (S.D. Miss. Jan. 24, 2012) (filing racial harassment claims against the company under Title VII).

184. See David, 588 F. Supp. $2 d$ at 722.

185. No. 11-00257, 2011 U.S. Dist. LEXIS 127734, at*47 (D. Haw. Nov. 2, 2011).

186. Complaint, EEOC v. Global Horizons, Inc., No. 11-cv-03045-EFS, 2012 U.S. Dist. LEXIS 105993 (E.D. Wash. July 27, 2012); see also First Amended Complaint, U.S. EEOC v. Global Horizons, Inc. at 9, No. 11-cv-00257-DAE-RLP, 2011 U.S. Dist. LEXIS 127734 (D. Haw. Nov. 2, 2011) ("Global [Horizons] — often with the help of the agricultural companies and farms with which it contracted-subjected the Claimants to different terms and conditions of employment and engaged in a pattern or practice of such acts based on the Claimants' Thai national origin and Asian race.").

187. Complaint, supra note 186 . The case in the District of Hawaii was recently dismissed without prejudice against the growers that contracted with Global Horizons. EEOC v. Global Horizons, No. 11-00257, 2011 U.S. Dist. LEXIS 127734, at *47 (D. Haw. Nov. 2, 2011). The court stated that the EEOC had failed to sufficiently plead how the growers were involved in the racial discrimination alleged against Global Horizons. Id. at*35-36.

188. One earlier case involving guest workers settled after the filing of the complaint. Consent Decree, EEOC v. Trans Bay Steel Corp., No. 06-cv-07766 (C.D. Cal. Dec. 8. 2008).
} 
discrimination cases, courts consider the "totality of the circumstances" in evaluating whether the harms are sufficiently severe and pervasive to create a hostile work environment. ${ }^{189}$ In particular, Martha Chamallas has explained that "room has been cleared for fact finders to consider the background social identities of the actors and power dynamics at the workplace before they decide whether actionable harm has occurred." 190 Such contextual analysis has allowed courts to find, for example, that verbal abuse and threats of physical violence that were not overtly sexual could constitute sexual harassment. ${ }^{191}$ Facially neutral abusive conduct can support a finding of discrimination sufficient to sustain a hostile-workenvironment claim when the conduct is viewed in the context of other overtly discriminatory conduct. ${ }^{192}$ Similarly, the confiscation of documents, threats of deportation, and false imprisonment can help establish a hostile work environment claim if coupled with other discriminatory conduct, such as derogatory comments or insults, against guest workers. ${ }^{193}$

Seemingly neutral acts of intimidation and abuse that are endemic to guest worker programs can assist in constructing a claim of harassment based on race or national origin. Examining the totality of the circumstances provides an opportunity to explain how the power dynamics of guest worker programs can lend themselves to a hostile work environment. Further, the advantage of pleading such neutral acts of intimidation and abuse that appear criminal in nature is that they are objectively severe. ${ }^{194}$ Antidiscrimination laws,

189. 29 C.F.R. § 1604.11(b) (2011).

190. Martha Chamallas, Discrimination and Outrage: The Migration from Civil Rights to Tort Law, 48 WM. \& MARY L. REV. 2115, 2175 (2007).

191. See, e.g., Chavez v. New Mexico, 397 F.3d 826, 833 (10th Cir. 2005); Carter v. Chrysler Corp., 173 F.3d 693, 701 (8th Cir. 1999); McKinney v. Dole, 765 F.2d 1129, 1138-39 (D.C. Cir. 1985).

192. Chavez, 397 F.3d at 835-36.

193. An employer who is not directly involved in the harassment can still be held liable for a hostile work environment created by its supervisors under the theories of vicarious liability or because of negligence. Burlington Indus., Inc. v. Ellerth, 524 U.S. 742, 765 (1998); Faragher v. Boca Raton, 524 U.S. 775, 807 (1997); Davis v. U.S. Postal Serv., 142 F.3d 1334, 1342 (10th Cir. 1998).

194. Sahar F. Aziz, Sticks and Stones, The Words that Hurt: Entrenched Stereotypes Eight Years After 9/11, 13 N.Y. CITY. L. REV. 33, 57 (2009) (noting that racial-harassment cases alleging threats of physical harm were more likely to survive summary judgment). 
therefore, can give guest workers another vehicle to address their employers' exploitative acts.

\section{EMPOWERMENT OF \\ GUEST WORKERS}

Private civil remedies can serve to empower guest workers. The $\mathrm{H}-2 \mathrm{~A}$ cattle herders discussed in the Introduction of this Article brought their own civil action utilizing private rights of action under the TVPA and civil RICO. ${ }^{195}$ They were able to allege, for example, that their employer used threats of deportation as coercion to subject them to forced labor under the TVPA. ${ }^{196}$ Under civil RICO, plaintiffs claimed that defendants had engaged in a pattern and practice of visa fraud by requiring them to perform work that was unauthorized by their visas. ${ }^{197}$ Further, plaintiffs alleged that defendants' use of threats and intimidation, including an attempt to get one worker to rescind his workers' compensation claim, amounted to the wrongful use of fear under the civil RICO predicate act of extortion. ${ }^{198}$ In making such claims, these workers were able to control their own case and did not have to rely on the governmental agencies that ultimately failed them. Rather, they were able to achieve a resolution on their own terms, which, in addition to monetary damages, provided injunctive-type relief requiring the employer to implement new policies monitored for a period of two years. ${ }^{199}$

The use of private civil remedies, therefore, can create worker agency by vindicating individual rights and enforcing workplace norms. Guest workers need not rely on government agencies that shift enforcement priorities with each change in administration and also lack the resources or will to enforce the laws. ${ }^{200}$ Nor need they

195. Velasquez Catalan v. Vermillion Ranch Ltd. P'ship, No. 06-cv-01043, 2007 U.S. Dist. LEXIS 567 (D. Colo. Jan. 4, 2007).

196. Id. at *24.

197. Id. at *18-20.

198. Id. at $* 24$.

199. Settlement and General Release Agreement at iii, Velasquez Catalan, No. 06-cv-01043 (D. Colo. May 28, 2008) (on file with author). The terms of the agreement required the employer, for example, to develop an employee handbook in Spanish, permit workers to occasionally take trips off the ranch, and facilitate the purchase of cell phones. Id. at iii-iv.

200. Stumpf \& Friedman, supra note 16, at 135 (explaining that the private right of action under the civil-rights laws was to address the concern that "the State will be less likely to exercise 
rely on a feckless regulatory system that fails to reach the more egregious abuses by employers. Rather, they can, on their own initiative, use private civil remedies to address employer exploitation and request compensatory damages, punitive damages, or injunctive relief. ${ }^{201}$ In the process, they can contribute to creating new legal precedents that help advance the laws combating workplace exploitation. $^{202}$ The award of damages can provide vindication to plaintiffs that they have achieved some form of justice and positively impacted the lives of existing workers or future employees. ${ }^{203}$

Guest workers potentially have increased access to the use of these private civil remedies because they provide for attorneys' fees. $^{204}$ The availability of attorneys' fees expands the pool of available lawyers beyond the limited resources of the nonprofit organizations that have traditionally represented underserved guest workers. The additional complexities that arise from litigating a case on behalf of guest workers, however, may practically limit the willingness of some within the private bar to take on such cases. ${ }^{205}$

its power on behalf of those who, lacking a majority in a democratic society, have less influence on the political process").

201. 18 U.S.C. $§ 1964(\mathrm{c})$ (2006); 42 U.S.C. $\S \S 2000 \mathrm{e}-5(\mathrm{~g})(1), 1981 \mathrm{a}(\mathrm{a})(1)$. Civil RICO provides for treble damages. 18 U.S.C. $\S 1964(\mathrm{c})$. Title VII and 42 U.S.C. $§ 1981$ can provide for back pay, compensatory damages, and punitive damages. 42 U.S.C. $\S \S 1981 \mathrm{a}(\mathrm{a})(1), 2000 \mathrm{e}-$ 5(g)(1); Johnson v. Ry. Express Agency, Inc., 421 U.S. 454, 459 (1975). Title VII has caps on compensatory and punitive damages, but 42 U.S.C. $\S 1981$ does not. 42 U.S.C $\S \S 1981 \mathrm{a}(\mathrm{b})(3), 2000 \mathrm{e}-5(\mathrm{~g})$. The TVPA provides for "damages," which are not defined. 18 U.S.C. $\S 1595$ (a). Punitive damages are available under the TVPA. Ditullio v. Boehm, 662 F.3d 1091, 1098 (9th Cir. 2011). Under a state analog statute, treble damages are awarded. See, e.g., CAL. CIV. CoDE $§ 52.5$ (b) (West 2007).

202. See, e.g., Kim, supra note 31, at 293-94 (discussing how the use of the private right of action under the TVPA has created important precedents and advanced legal norms).

203. In Aguilar v. Imperial Nurseries, for example, twelve guest workers received a default judgment of $\$ 7.7$ million for claims that included human trafficking and civil RICO. No. 3-07-cv193 (JCH), 2008 U.S. Dist. LEXIS 48404, at *4 (D. Conn. May 28, 2008); see also CunninghamParmeter, supra note 32, at 1406 ("The individual enforcement of workplace norms benefits several groups of workers, including the plaintiff, her coworkers, and future employees who join a workplace reformed (hopefully) by their predecessor's actions."); Kim, supra note 31, at 293 (discussing how the private right of action under the TVPRA provides for more effective deterrence); Stumpf \& Friedman, supra note 16, at 135 (discussing how civil-rights statutes increase the level of compliance with antidiscrimination laws through the use of private individuals who act in the place of the State).

204. 18 U.S.C. $\S \S 1595(\mathrm{a}), 1964(\mathrm{c}) ; 42$ U.S.C. $\S \S 2000 \mathrm{e}-5(\mathrm{k}), 1988(\mathrm{~b})$.

205. Cathleen Caron, Portable Justice, Global Workers, and the United States, Clearinghouse ReV., Jan.-Feb. 2007, at 549, 551 (describing how the transnational migration of immigrant workers presents hurdles to legal cases); Susan Reed \& Ilene J. Jacobs, Serving 
Nonetheless, the availability of attorneys' fees increases the ability of those without adequate resources to enforce the law, ${ }^{206}$ and it can give increased access to legal representation for guest workers to vindicate their rights.

Through these private civil remedies, guest workers can also access the courts to tell their stories. Storytelling can have a cathartic effect as well as promote solidarity among workers. ${ }^{207}$ Further, this telling of stories can contribute to the counternarrative about guest worker exploitation in the public discourse. ${ }^{208}$ Cases involving private civil remedies have helped to create a counternarrative that undermines the dominant assumption that guest worker programs provide a convenient solution to both employers with labor shortages and immigrant workers seeking jobs. ${ }^{209}$ In particular, high-profile guest worker cases have most likely contributed to policy changes to the guest worker programs, but they have not been enough to eradicate the programs. ${ }^{210}$ The increased use of private civil remedies

Farmworkers, Clearinghouse ReV., Sept.-Oct. 2004, at 367, 369 (describing the linguistic and cultural challenges in representing farm workers).

206. Jack B. Weinstein, Adjudicative Justice in a Diverse Mass Society, 8 J.L. \& PoL'Y 385, 390-91 (2000) (citing fee shifting as a grounds for opening the adjudication system to all); see also Evans v. Jeff D., 475 U.S. 717, 741 (1986) (finding that "the Fees Act has given the victims of civil rights violations a powerful weapon that improves their ability to employ counsel, to obtain access to the courts, and thereafter to vindicate their rights by means of settlement or trial"). There has recently been a sharp increase in cases brought under the Fair Labor Standards Act (FLSA) on behalf of low-wage workers. Nantiya Ruan, Facilitating Wage Theft: How Courts Use Procedural Rules to Undermine Substantive Rights of Low-Wage Workers, 63 VAND. L. REV. 727, 735 (2010) (suggesting that the increased number of cases seeking to recover wages from employers is due, in part, to the "increased number of plaintiffs' lawyers successfully pressing wage claims").

207. Richard Delgado, Storytelling for Oppositionists and Others: A Plea for Narrative, 87 MiCH. L. REV. 2411, 2437 (1988).

208. Eric K. Yamamoto, Critical Race Praxis: Race Theory and Political Lawyering Practice in Post-Civil Rights America, 95 Mich. L. REV. 821, 888 (1997); see also Sameer M. Ashar, Public Interest Lawyers and Resistance Movements, 95 CALIF. L. REV. 1879, 1917 (2007) (describing how the strategies of litigation and protest by workers against private actors were for the "audience" of city council members and government agency personnel).

209. See, e.g., Nina Bernstein, Suit to Charge that Nursery Mistreated Laborers, N.Y. TIMES, Feb. 8, 2007, at B2 (describing a trafficking lawsuit on behalf of Guatemalan workers who had large recruitment debts and whose passports were confiscated); Steven Greenhouse, Low Pay and Broken Promises Greet Guest Workers, N.Y. TIMES, Feb. 28, 2007, at A1 (describing a trafficking lawsuit on behalf of Thai workers who paid exorbitant recruitment fees to a contractor for jobs in the United States).

210. The recently revised $\mathrm{H}-2 \mathrm{~A}$ and $\mathrm{H}-2 \mathrm{~B}$ regulations, for example, now explicitly prohibit the confiscation of passports and require employers to contractually prohibit any of their agents 
by guest workers can publicly expose how these programs sanction, if not promote, criminal exploitation. The resulting narratives can confer legitimacy on the necessary agenda of substantially modifying or eradicating guest worker programs that compromise individual liberty. $^{211}$

While the discussion in this Article has thus far focused on guest workers, private civil remedies can be extended to the much larger population of immigrant workers who work without authorization ("unauthorized migrants") to vindicate their rights. In John Does I-V v. Rodriguez, ${ }^{212}$ for example, unauthorized migrants sued under both the TVPA and civil RICO based on allegations that they worked and lived under constant surveillance to pay off smuggling debts. ${ }^{213}$ The workers reached a settlement with some parties and received a default judgment of $\$ 7.8$ million against others. ${ }^{214}$ In another example, Montano-Perez v. Durrett Cheese Sales, Inc., ${ }^{215}$ unauthorized migrants sued under 42 U.S.C. $\$ 1981$ for a hostile and abusive work environment, alleging that their employer threatened not only to withhold their pay but also to call authorities to have them arrested and detained. ${ }^{216}$ The case settled for a court-enforced judgment of $\$ 75,000 .{ }^{217}$ While unauthorized migrants can employ private civil remedies, it should be recognized that they may not be able to access the full range of damages because of Hoffman Plastics Compounds v. NLRB. ${ }^{218}$ In Hoffman Plastics, the Court held that the NLRB could not award an undocumented worker with back pay as a remedy. ${ }^{219}$ While the impact of Hoffman Plastics is still developing

from charging recruitment fees. See, e.g., 20 C.F.R. $\S \S 655.135(\mathrm{e}),(\mathrm{j})-(\mathrm{k}), 655.20(\mathrm{o})-(\mathrm{p}),(\mathrm{z})$ (2012).

211. Elmore, supra note 27, at 541; Ontiveros, supra note 43, at 928; Wishnie, supra note 15, at 1455-56. Mary Lee Hall has noted the irony that undocumented farm workers have noted that they had more liberty than H-2A farm workers. Hall, supra note 12, at 536.

212. No. 06-cv-00805 (D. Colo. Apr. 13, 2009).

213. Complaint, John Does I-V v. Rodriguez, No. 06-cv-00805 (D. Colo. Apr. 26, 2006).

214. John Does I-V, No. 06-cv-00805, slip op. at 2; see also Felisa Cardona \& Kevin Vaughan, Fields of Fear for Colorado Illegal Farm Laborers, DENVER Post, May 17, 2009, http://www.denverpost.com/ci_12387869 (reporting on the judgment).

215. No. 08-cv-01015 (M.D. Tenn. Oct. 16, 2008).

216. Complaint, Montana-Perez, No. 08-cv-01015.

217. Montano-Perez, No. 3:08-cv-01015, slip op. at 1.

218. 535 U.S. 137 (2002).

219. Id. at 151-52. The worker had obtained the job by presenting fraudulent documents, and the employer had not known that the worker was undocumented at the time of hire. Id. at 141. 
with respect to the availability of back pay for unauthorized workers, ${ }^{220}$ courts have reaffirmed that certain damages still remain available, such as unpaid wages for work performed, compensatory damages for pain and suffering, and punitive damages. ${ }^{21}$ Unauthorized migrants, therefore, can similarly use such private civil remedies to take control of their own claims by seeking damages while telling their story of exploitation. ${ }^{222}$

By focusing on criminal exploitation by employers, the use of private civil remedies has the potential to reframe the debate about immigrant workers and broaden the discussion to include the exploitation of all low-wage workers. Government policies that have criminalized immigration law and subsequently led to the increased prosecution of immigrant workers ${ }^{223}$ have cultivated the public perception of immigrant criminality. ${ }^{224}$ The use of private rights of

220. See, e.g., Madeira v. Affordable Hous. Found., Inc., 469 F.3d 219, 248 (2d Cir. 2006) (finding Hoffman inapplicable to a claim for compensatory damages based on lost earnings in a personal-injury case where the employer had knowingly violated immigration laws in hiring the worker); Avila-Blum v. Casa De Cambio Delgado, Inc., 236 F.R.D. 190, 192 (S.D.N.Y. 2006) (citing Rivera v. Nibco, Inc., 364 F.3d 1057 (9th Cir. 2004)) (suggesting that Hoffman may not be applicable to the collection of back pay for Title VII violations).

221. In the FLSA context, courts have explicitly determined that workers are eligible for compensatory and punitive damages for unlawful retaliation. See, e.g., Renteria v. Italia Foods, Inc., No. 02-C-495, 2003 U.S. Dist. LEXIS 14698, at*19-20 (N.D. Ill. Aug. 21, 2003); Singh v. Jutla \& C.D. \& R's Oil, Inc., 214 F. Supp. 2d 1056, 1061 (N.D. Cal. 2002).

222. Ashar, supra note 208, at 1921 (noting that immigrant workers who initiate "litigation can, at least partly, compensate for their lack of legal status" since it can assist them with otherwise "assert[ing] countervailing power in their workplaces and communities").

223. Much has been written on the criminalization of immigration law. See, e.g., Daniel Kanstroom, Criminalizing the Undocumented: Ironic Boundaries of the Post-September 11th “Pale of Law”, 29 N.C. J. INT'L L. \& COM. REG. 639, 653-55 (2004); Stephen H. Legomsky, The New Path of Immigration Law: Asymmetric Incorporation of Criminal Justice Norms, 64 WASH. \& LEE L. REV. 469 (2007); Teresa A. Miller, Blurring the Boundaries Between Immigration and Crime Control After September 11th, 25 B.C. THIRD WORLD L.J. 81 (2005); Teresa A. Miller, Citizenship and Severity: Recent Immigration Reforms and the New Penology, 17 GEO. IMMIGR. L.J. 611 (2003); Dinesh Shenoy \& Salima Oines Khakoo, One Strike and You're Out! The Crumbling Distinction Between the Criminal and the Civil for Immigrants in the Twenty-First Century, 35 WM. Mitchell L. REV. 135 (2008); Stumpf, supra note 19, at 367. The increased collaboration between local law enforcement and federal immigration authorities has chilled the ability of immigrant workers to enforce their rights and made them more prone to exploitation. Ashar, supra note 208, at 1887-88; Saucedo, supra note 31, at 900. Further, the increased use of criminal prosecutions of immigrant workers after "silent raids" has further driven workers underground. Ong Hing, supra note 16.

224. Jennifer M. Chacón, Unsecured Borders: Immigration Restrictions, Crime Control and National Security, 39 CONN. L. REV. 1827, 1839-40 (2007) (discussing mental linkages between crime and immigration); Bill Ong Hing, The Immigrant as Criminal: Punishing Dreamers, 9 HASTINGS WOMEN'S L.J. 79, 85-86 (1998) (describing how U.S. policies have criminalized "the 
action under the TVPA, civil RICO, and antidiscrimination laws can shift the focus from the presumption of the criminality of immigrants to the actual criminal conduct of the employer in exploiting workers. Hiroshi Motumura has noted that courts are more willing to recognize the rights of unauthorized migrants when the employer is engaged in more serious wrongdoing. ${ }^{225}$ Further, the criminality of employers has advanced immigrant workers' rights in other arenas by broadening the discussion to the exploitation of all low-wage workers. The movements to end wage theft have successfully emphasized the criminality of employers through direct actions by publicly shaming employers and pushing to criminalize the nonpayment of wages. ${ }^{226}$ Laws that punish employers for criminal exploitation of all workers can be more politically palatable because they appear facially neutral on the inflammatory question of immigrants. The passage of laws addressing wage theft has occurred, in part, because broad coalitions of low-wage workers have come together to push such legislation. ${ }^{227}$ By comparatively characterizing the employer's wrongdoing as criminal, private civil remedies can potentially contribute to reshaping the public's imagination about immigrant workers and can frame worker exploitation within the greater context of the government's failure to protect all low-wage workers.

Any discussion about using private civil remedies as part of a broader strategy to vindicate immigrant workers' rights, however, must be balanced against a reality in which workers legitimately fear reporting workplace exploitation. It is well known that all immigrant workers, whether unauthorized migrants or guest workers, are

\footnotetext{
immigrant's actions, status, and dreams"). Recent government actions continue to highlight the criminality of immigrants. Jeff Bliss, U.S. Arrests 2,900 Illegal Immigrant Criminals in Crackdown, BuS. WK., Sept. 28, 2011, http://www.businessweek.com/news/2011-09-28/u-s -arrests-2-900-illegal-immigrant-criminals-in-crackdown.html; Julia Preston, Resistance Widens to Obama Initiative on Criminal Immigrants, N.Y. TIMES, Aug. 13, 2011, at A11.

225. Motomura, supra note 16, at 1750-51.

226. THEODORE, supra note 25 , at $12,16-17$. Nik Theodore notes that the term "wage theft" did not appear in any major newspapers or print sources until 2005. Id. at 21-22.

227. Deborah Axt et al., The Campaign to Pass New York's Wage Theft Prevention Act, CLEARINGHOUSE REV., Jul.-Aug. 2011, at 157 (describing the unanimous support from labor for the Wage Theft Prevention Act, S. 8380/A. 11726 (2010) (codified at N.Y. LABOR LAW §§ 19599, 215-19, 661-63)); THEODORE, supra note 25, at 16 (describing the coalitions that worked on the Illinois Wage Payment and Collection Act, 820 ILl. COMP. STAT. 115. (2010)).
} 
reluctant to report exploitation, much less use the judicial system to enforce their rights, largely because of fear of retaliation and deportation. ${ }^{228}$ Outreach and education efforts, in collaboration with community-based organizations, provide information to workers about their rights so that they can make informed choices about their options. ${ }^{22}$ The availability of crime-related victim visas can provide some protection that may tip the balance toward convincing certain immigrant workers to come forward. ${ }^{230}$ Further, in a number of cases filed by immigrant workers, courts have prohibited discovery into immigration status, finding that the prejudicial impact of the disclosure of such information was outweighed by its irrelevance to the claims of workplace exploitation. ${ }^{231}$ In cases where workers fear retaliation by the employers, such as blacklisting, deportation, and

228. AFL-CIO, IMMIGRANT WORKERS AT RISK: THE URGENT NEED FOR IMPROVED WORKPlace SAFETY AND HEAlth POLICIES AND PROGRAM 7-8 (2005) (describing the underreporting of health and safety violations by immigrant workers because of retaliation fears); Caron, supra note 205, at 551 (describing the workers' fear of retaliation and lack of knowledge about rights or where to obtain legal assistance); Stumpf \& Friedman, supra note 16, at 143-44 (describing a lack of information, cultural barriers, few resources, and high turnover as hurdles to enforcement); Michael J. Wishnie, Immigrant and the Right to Petition, 78 N.Y.U. L. REV. 667, 678-79 (2003). See supra Part II.A for a discussion on the climate of fear among guest workers.

229. Ingrid V. Eagly, Community Education: Creating a New Vision of Legal Services Practice, 4 CliniCAL L. REV. 433, 449 (1998).

230. Chacón, supra note 27, at 3011 (noting the provision of $\mathrm{T}$ visas for victims of a severe form of human trafficking); Kim, supra note 31, at 307 (discussing the TVPA's authorization of continued presence for trafficked workers); Saucedo, supra note 31, at 939 (noting that the U visa can serve the purpose of "protecting workers and empowering them to come forward"); see also Garcia v. Audobon Communities Mgmt., LLC, No. 08-cv-01291, slip op. at 7 (E.D. La. Apr. 15, 2008) (granting U visa certifications to undocumented plaintiffs based on their criminal exploitation). Further, federally funded legal-services organizations are able to represent individuals who qualify for crime victim visas. Letter from Helaine M. Barnett, President, Legal Servs. Corp., to LSC Program Dirs., (Feb. 21, 2006), available at http:/grants.lsc.gov/rin /grantee-guidance/program-letters/current-program-letters (Program Letter 06-2); Letter from Helaine M. Barnett, President, Legal Servs. Corp., to LSC Program Dirs., (Oct. 6, 2005), available at http://grants.lsc.gov/rin/grantee-guidance/program-letters/current-program-letters (Program Letter 05-2).

231. See, e.g., Rivera v. Nibco, Inc., 364 F.3d 1057, 1074-75 (9th Cir. 2004); In re Reyes, 814 F.2d 168, 170-71 (5th Cir. 1987); EEOC v. First Wireless Grp., Inc., 225 F.R.D. 404, 406-07 (E.D.N.Y. 2004); Topo v. Dhir, 210 F.R.D. 76, 79 (S.D.N.Y. 2002); Liu v. Donna Karan Int'l, Inc., 207 F. Supp. 2d 191, 192-93 (S.D.N.Y. 2002); Flores v. Amigon, 233 F. Supp. 2d 462, 464 65 (E.D.N.Y. 2002); see also Hernandez v. City Wide Insulation of Madison Co., No. 05C0303, 2006 U.S. Dist. LEXIS 86756, at*3-4 (E.D. Wis. Nov. 30, 2006) (denying a discovery request regarding immigration status to invalidate the credibility of plaintiffs); Cortez v. Medina's Landscaping, No. 00C6320, 2002 U.S. Dist. LEXIS 18831, at *2-3 (N.D. Ill. Sept. 30, 2002) (holding that immigration status has no bearing on claims for unpaid wages related to work that was performed) 
violence, workers may be able to initiate a lawsuit anonymously. ${ }^{232}$ Worker-organizing and community-based organizations can also give significant support to workers who seek legal redress for exploitation. ${ }^{233}$ While none of these tools will manage to completely extinguish fears associated with reporting workplace exploitation, they can give some modicum of encouragement to immigrant workers who consider using private civil remedies against their employer.

Private civil remedies have other constraints. They cannot be the mainstay in the political strategy of achieving social reform for guest workers. Nor do the particular private remedies discussed, the TVPA, civil RICO, and antidiscrimination laws, even presume to solve the ills facing immigrant workers, as they only address fairly egregious forms of exploitation. Yet these remedies do offer a paradigmatic mechanism for exercising individual worker agency, assisting collective efforts to enforce workplace norms, and contributing to the legal development of remedies to the benefit of all workers. $^{234}$ Counternarratives created from the use of the legal system can positively influence policy reform and lend legitimacy to the movement of immigrant workers, thereby contributing to overall worker empowerment. ${ }^{235}$ The use of such remedies, therefore, should be carefully coordinated with collective worker strategies, such as organizing, education, and policy reform, which have proved important to the fight against the exploitation of immigrant workers. ${ }^{236}$ On balance, the use of private remedies can be viewed as a successful part of the parcel of strategies for advancing guest workers' rights.

232. Does I-XXIII v. Advanced Textile Corp., 214 F.3d 1058, 1068-73 (9th Cir. 2000); Javier v. Garcia-Botello, 211 F.R.D. 194, 196 (W.D.N.Y. 2002).

233. Ashar, supra note 208 , at 1910 (describing "construction of a tripartite relationship between lawyers, workers, and organizers").

234. At times, the enforcement of individual rights can serve as a more effective vehicle for achieving collective ends and impacting regulation of the workplace. In North Carolina, a lawsuit brought by H-2A workers using private civil remedies resulted in leverage that a farm-worker union used to achieve the first collective-bargaining agreement for guest workers in the country. Acosta v. Beasley, No. 04 CV 005067 (N.C. Super. Ct. filed Apr. 13, 2004); Interview with Lori Johnson, Attorney, Legal Aid of N.C. (Jan. 28, 2013).

235. Yamamoto, supra note 208 , at $888-89$.

236. THEODORE, supra note 25 , at 12-13, 25 (discussing examples of combined organizing and litigation strategies); see also Ashar, supra note 208, at 1910; Cummings \& Eagly, supra note 32 , at $491-92$. 


\section{CONCLUSION}

This Article has illustrated the positive attributes that come with the devolution of rights from the federal government to individual workers by describing the potential power of private civil remedies for guest workers who suffer from workplace exploitation. Without private civil remedies, the $\mathrm{H}-2 \mathrm{~A}$ cattle herders at the Introduction of this Article would have had no recourse and been left to suffer as passive victims of an apathetic state. Instead, these workers had the opportunity to tell their own story while seeking justice for themselves and other workers. As the debate about the broken immigration system in the United States continues, lawmakers will continue to seek to expand current guest worker programs. ${ }^{237}$ Based on its past record, the government will likely continue to fail to stem the tide of the endemic abuses associated with these programs. Guest workers, therefore, will continue to need to look toward private civil remedies as a means of enforcing their rights and improving workplace conditions. To this effect, private civil remedies can play a modest role in the movement to realize full labor and employment protections for immigrant workers.

237. See, e.g., Adam Van Brimmer, State Ag Commish: Feds Must Act on Guest Worker Program, SAVANNAH MoRning News, Jan. 6, 2012, available at 2012 WLNR 360924; Marc Heller \& Brian Amaral, Visa Program for Workers Is Unworkable, Owens Says, WATERTOWN DAILY TIMES, Mar. 31, 2011, available at 2011 WLNR 6216136; George Prentice, Obama: U.S. Needs Immigration Reform; Crapo Suggests Guest Worker Program, BoISE WKLY., May 10, 2011, http://www.boiseweekly.com/CityDesk/archives/2011/05/10/obama-us-needs-immigration -reform-crapo-suggests-guest-worker-program. 
